YATIRIMCILARIN DUYGUSAL VE BILISSSEL EĞILIMLERINIIN DEĞERLENDİRILMESİ: ERZİNCAN İLİ UYGULAMASI

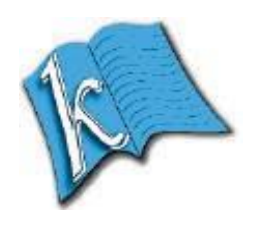

Kafkas Üniversitesi İktisadi ve İdari Bilimler Fakültesi

$$
\text { KAÜİ̈BFD }
$$

Cilt, 9, Sayı 18, 2018

ISSN: $1309-4289$

E- ISSN: 2149-9136

Makale Gönderim Tarihi:18.04.2018 Yayına Kabul Tarihi: 22.05.2018

ÖZ Davranışsal finans, yatırımcıların yatırım

Ali ÖZER

Dr. Öğr. Üyesi

Erzincan Binali Yıldırım

Üniversitesi

İktisadi ve İdari Bilimler

Fakültesi

aliozer@erzincan.edu.tr

ORCID ID: 0000-0003-

4736-3418

Duygu

KORKULUTAŞ

Yüksek Lisans Öğrencisi Erzincan Binali Yıldırım

Üniversitesi

Sosyal Bilimler Enstitüsü dbasuguy@gmail.com

ORCID ID: 0000-00034971-543X kararlarında risk ve getiri dışında başka değişkenleri de göz önüne aldıklarını ve alınan kararların, faydayı maksimize eden değil, karar alıcı mekanizmanın tatmin olduğu kararlardan oluştuğu varsayımlarına dayanmakta olup son yıllarda oldukça önem kazanan bir alandır. Bazen psikolojik ve kişilikten kaynaklanan yatırımcı davranışları, bazen de bireyin etkileşimde bulunduğu sosyal faktörler bireylerin yatırım kararları üzerinde etkili olabilmektedir. Davranışsal finans, finans piyasalarında yatırımcıların nasıl hareket etmeleri gerektiği yani yatırım davranışlarının analizi konusunda finans bilim dünyasına 1şık tutmaktadır. Bu çalışmada Erzincan ilindeki bireysel yatırımcıların yatırım kararlarına etki eden faktörleri belirlemek adına anket çalışması yapılmıştır. Çalışma sonucunda, davranışsal eğilimlerin yatırım kararlarında oldukça büyük bir etkiye sahip olduğu tespit edilmiştir.

Anahtar Kelimeler: Davranışsal Finans, Yatırımcı

Davranışları, Erzincan

JEL Kodu: G11, G19, G41

Alanı: İşletme

Türü: Araştırma

DOI:10.9775/kauiibfd.2018.017

Atıfta bulunmak için: Özer, A. \& Korkulutaş, D. (2018). Yatırımcıların duygusal ve bilişsel eğilimlerinin değerlendirilmesi: Erzincan ili uygulaması. KAÜIIIBFD, 9(18), 391-420. 


\section{EVALUATION OF EMOTIONAL AND COGNITIVE TRENDS OF INVESTORS: THE CASE OF ERZINCAN}

Article Submission Date: 18.04.2018

Accepted Date: 22.05.2018

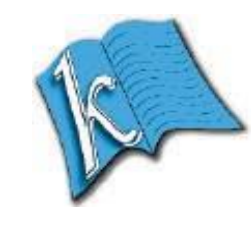

Kafkas Üniversity Economics and Administrative Sciences Faculty KAUJEASF

Vol. 9 , Issue 18,2018

ISSN: $1309-4289$

E- ISSN: 2149-9136
Ali ÖZER

Assistant Professor

Erzincan Binali Yıldırım

University

Faculty of Economics

and Administrative

Sciences

aliozer@erzincan.edu.tr

ORCID ID: 0000-0003-

4736-3418

Duygu

KORKULUTAŞ

Graduate Student

Erzincan Binali Yıldırım

University

Faculty of Economics and Administrative

Sciences

dbasuguy@gmail.com

ORCID ID: 0000-0003-

4971-543X
ABSTRACT Behavioral finance; is a field that has gained considerable importance in recent years, based on the assumptions that investors take into account other variables besides risk and return when making investment decisions, and that the taken decisions are made to satisfy the decision maker rather than maximize utility. Sometimes, investor behaviors arising from psychological and personality, and sometimes social factors in which the individual interacts can have an impact on individual investment decisions. Behavioral finance sheds light on the world of finance science to show how investors should act in financial markets and also how to analyze the investment behavior. In this study, a survey was conducted in order to determine the factors affecting investment decisions of individual investors in Erzincan province. As a result of the study, behavioral trends have been found to have a considerable influence on investment decisions.

Keywords: Behavioral Finance, Investor Behavior, Erzincan.

Jel Codes: G11, G19, G41

Scope: Business

Type: Research

Cite this Paper: Özer, A. \& Korkulutaş, D. (2018). Evaluation of emotional and cognitive trends of investors: The case of Erzincan. KAUJEASF, 9(18), 391-420. 


\section{GİRIŞ}

Geleneksel finans teorilerinin temel varsayımlarından biri, bireylerin rasyonel kabul edilmesidir. Davranışsal finans yaklaşımında ise yatırımcılar, geleneksel finans modellerinin aksine irrasyonel olarak kabul edilmektedirler. Davranışsal finans teorisi, psikoloji ve sosyoloji bilim dallarından elde edilen bulguların finans alanına uygulanması ile oluşturulan teoridir. Davranışsal finans modelleri, rasyonel finans modellerinin açıklayamadığı yatırımcı davranışlarını ve bu davranışların neden olduğu ani fiyat değişimlerini inceler. "Anomali" olarak adlandırılan bu ani fiyat değişimlerin nedeninin insan psikolojisinden kaynaklanabileceği göz önüne alınarak ve karar alma süreçlerine psikolojik faktörlerin de eklenmesi, davranışsal finansın ortaya çıkmasına zemin hazırlamıştır (Karan, 2013: 720). Davranışsal Finans, normalde rasyonel kararlar alan bireyin, karar alırken istatistiki verilere ek olarak psikoloji, çevre ve geçmişe ait tutumlardan etkilenmesi sonucu ortaya çıkan disiplindir (Aldemir, 2015: 34). Bu bağlamda geliştirilen davranışsal finans modelleri, rasyonel modellerin yeterli bir şekilde açılayamadığ 1 yatırımcı davranışlarını açıklamak amacıyla geliştirilmiş olup geleneksel finans modellerini geçersiz saymıştır (Karan, 2006: 692).

Davranışsal finans modellerinden temsili yatırımcı modeli Barberis vd. (1998) tarafindan ortaya çıkarılmıştır. Modelde yatırımcının muhafazakârlık ve temsil edilebilirlik yanlılığ gibi algı yanılsamaları, aşırı reaksiyon ve yetersiz reaksiyona sebep olmaktadır. Muhafazakârlık, kârın belirli bir yönde değişiklik göstermesi sonucu yatırımcının mevcut durumun tekrar en uygun düzeye ineceğine inandıklarında oluşur ve düşük reaksiyona yol açar. Temsil edilebilirlik ise, yatırımcının aynı yönde oluşan birçok şaşırtıcı durumdan sonra yeni bir trend başladığına inandıkları zaman oluşmaktadır. $\mathrm{Bu}$ da aşırı reaksiyona neden olmaktadır (Barberis, vd., 1998: 310-317).

Aşırı güven ve yanlı atfetme modelinde temsili yatırımc1 modelinden farklı psikolojik alg1 yanılmalarına dayanmasına rağmen, temsili yatırımcı modeli ile aynı yönde sonuçlar elde edilmektedir. $\mathrm{Bu}$ model, hisse senedi fiyatlarının kişisel bilgilere aşırı reaksiyon, kamu bilgilerine ise düşük reaksiyon göstermesi üzerine kurgulanmıştır. Tek fark1, önyargılara dayanmalarına rağmen birbirleriyle paralel yönde sonuç üretmeleridir (Barak, 2008: 212).

Davranışsal Finans modellerinden sonuncusu ise interaktif ilişkiler modeli Hong \& Stein tarafından (1999) geliştirilmiştir. Temsili yatırımcı ve aşırı güven yanlı atfetme modelinden farklı olarak temsili yatırımcı psikolojisi değil, heterojen yatırımcıların arasında interaktif ilişki üzerine kurulmuştur. Momentum yatırımcıları ve haber avcıları diye adlandırılan bu yatırımcilar sınırlı rasyonel durumdadırlar. $\mathrm{Bu}$ nedenle kurumsal bilginin kullanıma açık 
olan çok küçük bir kısmı ile işlem yapabilmektedirler. Haber avcıları geçmiş ve mevcut döneme ait bilgilere sahip olmamakla birlikte sadece gelecek dönemlere ilişkin olarak edindikleri bilgilerle tahmin yapmaktadırlar. Haber avcıları adeta bir temel analist niteliğindedirler. Bu teoriye göre özel bilgi haber avcıları arasında yayılmaktadır. Haber avcılarının varlı̆̆ında aşırı reaksiyon olmamakta, düşük reaksiyon görülmektedir. Burada elde edilen özel bilgiler yatırımcılara yavaş bir şekilde özel duyumlarla aktarılır (Hong \& Stein, 1999: 2144). Momentum yatırımcilar, haber avcilarının tam aksine hareket edip sadece geçmiş bilgileri kullanıp, haber avcılarının neden olduğu eksik reaksiyonu tamamlarlar. Kullanılan basit stratejiler sayesinde piyasa verimli hale gelir, hisse senedine olan reaksiyon artar, fiyatlar daha da yükselir ve bu da uzun dönemde aşırı reaksiyona neden olur. Momentum yatırımcıları risk almadıkları zaman bile aşırı reaksiyona neden olmuşlardır (Barak, 2008: 213).

\section{DAVRANIŞSAL FINANS KAPSAMINDA YATIRIMCI EĞILIMLERI}

Davranışsal finans modellerinde incelenen yanılgılar olayları, zihindeki o anki varlıklarına göre değerlendiren, kişileri rasyonellikten uzaklaştıran yanıltıcı davranış şekilleri olarak tanımlanmaktadır (Taner \& Akkaya, 2005: 49). Zihinsel kestirme yollar olarak tanımlanan bilişsel kuramlar, sorulan sorulara biçimsel ilkelerden yararlanarak yanıt verildiğinde ve sezgilerle hareket edildiğinde ortaya çıkmaktadır. Belirsizlik durumlarında karar alma durumunda beliren bu yanlılıklar insanları gerçekçi olmayan sonuçlarla karşı karşıya bırakabilmektedir. Buna rağmen kestirme yollar yatırımcıların karar verme sürecine olumlu bir katkı yaparak değişmelerini de sağlayabilmektedir (Tomak, 2011: 74).

Bireylerin beklentilerini en üst seviyede tutmaları olarak açıklanan aşırı iyimserlik önyargısı, kişilerin gelecekle ilgili hayallerini normalüstü olarak görmektedir. İnsanların çoğu, öz eleştirilerini olumlu yönde yaparlarken kendilerini dünyanın merkezinde, başkalarını ise kendilerinden aşağ 1 görmektedirler. Gallup (2001)'un çalışmasında, yatırımcılardan bir yıllık borsa getirisini ve kendi portföy getirilerini tahmin etmeleri istenmiş, çalışma sonucunda kişilerin kendi portföy getirilerini daha yüksek oranda tahmin ettikleri görülmüştür (Küçük, 2014: 111).

Hatalarını yanlış değerlendirme eğilimi, kişinin kötü sonuçları dış unsurlarla bağdaştırması anlamına gelmektedir. Çünkü insanların genelinde, kötü bir durumla karşılaşınca bunun nedenini kendilerinde değil de kötü şans gibi başka faktörlerde aramak gibi davranışlar mevcuttur. Hataları yanlış değerlendirme eğilimi yatırımcıların aşırı güvenli olmalarıyla da çok yakından ilişkilidir. Hataların yanlış değerlendirilmesi sonucu, yapılan hatalardan ders 
alınamamakla birlikte hataların tekrarı söz konusu olabilmektedir (Böyükaslan, 2012: 96).

Sonucu bildiğini düşünme yanılgısı, herhangi bir olayın gerçekleşmesi sonrasında, kişinin bunun sonucunu daha önceden biliyormuş̧̧asına fikirlerini söylemleştirmesi ve değiştirmesi sonucu bildiğini düşünme olarak tanımlanmaktadır. Problemin çözümünü tam olarak bilmese bile çözümüne yardımcı olacak küçük detayları onaylamak, biliyormuşçasına hareket etmektir (Ede, 2007: 46).

Bir tür algısal yanılsama olan çerçeveleme etkisi, nesne ve olayların yanlış algılanması sonucu zihinde farklı yerlere oturtulması ile ortaya çıkmaktadır. $\mathrm{Bu}$ durumu düzeltmek için olayların doğru algılanmasını sağlayacak bir çerçeve içine alınması gerekir. Problem, bu çerçevenin oluşturulmasından kaynaklanmaktadır (Tufan \& Sarıçiçek, 2013: 173).

Muhafazakârlık eğilimi, Edwards tarafindan (1968) geliştirilmiş, bireylerin değişimin hızı karşısında pasif davranmaları, belli bir görüş ya da önyargılara inatla bağlanma eğilimi olarak tanımlanmıştır (Barak, 2008: 212). Muhafazakârlık, mevcut durumun korunması, örf, adet ve geleneklerimize ters gelen davranışlardan uzak durma gibi kültürel değerlerimizin bir gereğidir (Akman, 2009: 32).

Aşina olanı tercih etme eğiliminde ise bir olayın sonuçlarının bilinmediği belirsizlik durumlarında seçenekleri değerlendirmek yatırımcıları zor durumda bırakmaktadır. Riskli durumlar, gerçekleşmesine kesin gözüyle bakılan durumlardır. Belirsiz durumlar ise sonuç ve olay arasında bir bağlantının bulunduğu fakat gerçekleşme durumu ile ilgili herhangi bir fikrin olmadığı durumlardır. Yatırımcı bu durumda az da olsa aşina oldukları bir seçeneği hiç bilgi sahibi olmadıkları seçeneği tercih etmektedir. Yüksek risk faktörü içeren tercihlerde bile yatırımcı tanıdık bilinen seçeneğe yönelmektedir (Barak, 2006: 112).

Temsilcilik eğilimi bir şeyin olasılığını belirli bir kategorinin ne kadar temsil ettiğine göre karar verme yanılgısıdır. İnsan zihni benzer özelliklere sahip olan şeylerin büyük oranda benzer olduğu varsayımını kabul eder. Temsililik de sembolik olarak kategorize olmuş bilgilere dayalı kararlardan bahseder (Gümüş, Koç \& Agalarova, 2013: 77).

Aşırı veya düşük tepki verme eğiliminde hem deneyimsiz hem de profesyonel yatırımcılar duydukları yeni haberlere, geçmiş haberlerden daha çok değer verirler. Yeni haberlere verilen aşırı tepki sonucu yatırımcılar aşırı iyimserlik ya da aşırı kötümserlik eylemi göstermektedirler. Bu etki, fiyatların optimal değerlerinden ya çok yükselmesine ya da çok düşmesine sebep olmakta, 
bu değişim ilerleyen dönemlerde ters yönlü bir hareketle düzelme eğilimi göstermektedir. Düşük reaksiyon ise yeni bilgiye verilen geç tepki olarak tanımlanmıştır. Bunun nedeni olarak da yatırımcının tutucu davranışları olduğu öne sürülmüştür (Tufan \& Sarıçiçek, 2013: 171).

Bilişsel çelişki eğilimine göre, bireyin sahip olduğu inanç ve tutum yine aynı kişinin savunduğu bir başka inanç ve tutumun tersi ise bireyin bu iki düşüncesi arasında bilişsel çelişki var demektir. İnsanlar düşünceleri ve kararları ile bir olmayan bu bilgileri görmezden gelme reddetme veya bunları en aza indirme yolunu seçmektedirler. Birey için rahatsız edici olan bu çelişki durumu kişiyi bundan kurtulmanın yollarını aramaya itmektedir. (Altıngül, 2015: 17).

Mevcudiyet eğilimi, herhangi bir eylemin meydana gelme olasıllğının o eylemi hatırlatacak olan soruların akla geliş durumuna göre şekillenmesi olarak değerlendirilmektedir. Kolay hatırlanan eylemler zor hatırlananlara göre daha yüksek ihtimalle ortaya çıkmaktadır (Aslan, 2016: 44).

Demirleme eğilimi, insanlar problemlerin çözümünde veya karmaşık bir durumla karşılaş̧ıklarında bir referans noktası belirleme ihtiyacı hisseder. Rehber edinen bu temel nokta göz önünde tutularak çeşitli tahminler yapılır. Son durumda eklenen bilgilerle birlikte başlangıç değeri çıpalanarak düzeltilmektedir. Genellikle geçmiş deneyimlerle belirlenen bu referans noktası problemin küçük bir formülasyonu niteliğindedir. Çıpalama her iki durumda da yetersiz kalmaktadır (Şenkesen, 2009: 237).

Pişmanlıktan kaçınma eğilimi, kişiyi sergilediği davranışın tam tersini yapmış olması durumunda şu an olduğu durumdan daha iyi bir halde olacağına inandıran bilişsel tabanlı bir duygudur. Hissedilen pişmanlığın derecesi hatanın boyutu ile alakalı değildir; büyüklü küçüklü her türlü durumdan pişmanlık yaşanabilmektedir. Bu durum insanların zarar etmeye ya da başarısızlıklarını kabul etmeye meyilli değillerdir. Pişmanlık teorisi de insanların verdikleri kararlara etki eden pişmanlık duygusunun, bireye hatalı karar verdiren duygusal reaksiyonun üzerinde durmaktadır (Yıldız, Demir, Kalaycı \& Göksu, 2009: 95).

Oto kontrol eğilimi, kendi portföylerinde başarıyı yakalama konusunda oldukça önemli yer tutmaktadır. Zira yatırımcılar yoldan çıkarılmaya eğilimlidirler. $\mathrm{Bu}$ durumda kişi kendi portföyünün analisti olmalı, işlem stratejilerine disiplinli bir şekilde uymalıdır. Aksi takdirde zarar kaçınılmaz olacaktır (Küden, 2014: 59). Oto-kontrol eğilimi gösteren kişiler, kendilerini başarılı görmekte ancak dış etmenlerin başarısızlığı getirdiğine inanmaktadırlar. $\mathrm{Bu}$ yüzden yatırımcilar, fiyat hareketlerine karar verirken kendi bilgilerine ve performanslarına daha da fazla güvenmektedir (Tufan, 2006: 75).

Duygusal faktörlerin karar verme mekanizmasını etkilemesi ve bir takım 
sorunlarla karşılaşma olasılı̆̆ını arttırması sebebiyle bu faktörlerin bireylerin davranışları üzerine etkilerini belirlemek, bilişsel faktörlere göre çok daha zordur. İnsanların duygusal faktörlerden etkilenmesi duygusal bir varlık oluşundan kaynaklanmaktadır. Duygusal faktörler, bilgiyi kaydetme aşamasında insanların hissiyat yönünü ön plana çıkarmaktadır. Bu duygusal faktörler yatırım davranışlarında, içinde bulundukları duygusal faktörler etkili olmaktadir.

\section{LITERATÜR}

De Bondt ve Thaler (1985), çalışmalarında Amerikan piyasalarındaki verileri incelemiş, son beş yılda kazandıran ya da kaybettiren hisse senetlerinin, takip eden beş yılda öncekilere oranla daha az getiri sağladığını veya kaybettirdiğini ortaya koymuş, bunun aşırı reaksiyondan kaynaklandığı sunucuna varmışlardır.

Jegadessh ve Titman, (2001), çalışmalarında oluşturdukları portföyün orta ve uzun vadede momentum gösterip göstermediğini araştırmışlar, momentum yatırımcılarının geçmiş kazananlar portföyüyle anormal getiriler elde ettiklerini, bunun fiyat dalgalanmaları sırasında hız momentumu sayesinde elde ettiklerini yalnız bu etkinin orta vadede yaşandığını uzun vadede bu etkinin kaybolduğu sonucuna varılmıştır.

Baker ve Nofsinger (2002), yaptıkları çalışmada yatırım kararlarına etki eden faktörleri bilişsel ve davranışsal diye iki gruba ayırmıştır. Yatırımcıların karar verirlerken psikolojik ve sosyal etkileri içeren hatalar yaptıkları sonucuna varmışlardır.

Miffre ve Rallis (2007) ABD emtia sözleşmeleri üzerine yaptıkları çalışmalarında momentum yatırımcılarının geçmişte kazanan hisse senetlerinden oluşan portföyler sayesinde normalüstü getirinin sağlanacağ 1 sonucuna varılmıştır.

Rachev vd. (2007) çalışmalarında S\&P 500 endeksine ait hisse senedi verileri kullanılarak momentum anomalisi incelenmiş, analiz bulgularında kazanan ve kaybedenlerden oluşturulan portföylerin volatilitelerinin oldukça yüksek olduğu, bu stratejiyi uygulayacak yatırımcının bu yüksek oranda meydana gelen riski üstlenmesi gerektiğini vurgulamışlardır.

Süer (2007) çalışmasında, yatırım kararlarında alınan risk düzeyini belirlemek amacıyla davranışsal finans teorilerinin bir kısmını incelemiştir. Yatırımcıların, kazanırken riskten uzak durduklarını, kayıp durumunda ise riske meyilli bir tutum sergilediklerini; gelir-kar kavramlarını kazanç kavramıyla aynı zihinsel hesapta, harcama-maliyetin ise kayıp kavramıla aynı zihinsel hesapta tutulduğu sonucuna varılmıştır. 
Sümer ve Hepsağ (2007) finansal varlık fiyatlama modelleri çerçevesinde piyasa risklerinin hesaplanması ile ilgili bir çalışma yapmışlardır. Öncelikle parametrik regresyon modelleri ile risk tahmini yapılmıştır. Analiz sonucunda, hisse senedi yatırımlarında piyasa riski katsayılarının anormal tahminlerde bulunulmasına neden olduğu görülmüştür. Parametrik olmayan yöntemlerle hesaplanma durumunda ise piyasa riskleri tutarlı hal alacağından, yatırımcıların piyasadaki rollerinin daha rasyonel bir hâl alacağı sonucuna varılmıştır.

Çelik ve Taş (2007), zayıf etkinliği gelişmekte olan ülke piyasalarında incelemek ve ülkeler arası etkileşimin piyasalar üzerindeki etkisini tespit etmek amacıyla bir çalışma yapmışlardır. Çalışma sonucunda çoğu ülke için zayıf etkinliği destekler nitelikte bulgular elde edilmiştir.

Ateş (2007)'in, finansal yatırım aracı tercihleri ile yatırımcının finansal profilini değerlendirmek amacıyla bireysel yatırımcılar üzerinde yaptığı çalışma sonucunda, yatırımcının davranışsal ve finansal profilleri arasında anlamlı ilişkilerin olduğu görülmüştür.

Ede (2007), davranışsal finans kapsamında Türkiye'de bulunan bireysel yatırımcı davranışlarına ilişkin yaptığı çalışma sonucunda, psikolojik eğilimlerin bireysel yatırımcıların yatırım kararlarını önemli ölçüde etkilediği, bunun sonucunda rasyonellikten uzaklaştıkları sonucuna ulaşılmıştır. $\mathrm{Bu}$ durumun piyasaların etkinliğini azalttı̆̆ gözlenmiştir.

Barak (2008) çalışmasında aşırı reaksiyon anomalisinin dünya piyasalarında var olup olmadığını incelemiştir. Araştırma sonucu, etkin piyasalar hipotezinin BIST'de geçerli olamadığı, tüm davranışsal finans modellerinin anomalileri açıklamada farklı psikolojik önyargılara dayandığı fakat aynı yönde sonuç ürettiği görülmüştür. Ayrıca geçmişte kazandıran hisse senetlerinin sonraki dönemde kaybettirdiği, kaybettiren hisse senetlerinin ise sonraki dönemde kazandırdığı sonucuna varılmıştır.

Alper ve Ertan (2008), çalışmalarında "çerçeveleme etkisi" araştırmışlardır. Araştırma sonucu, yatırımcıların fon yöneticilerine güven duyduklarını, geçmiş performans verilerinin yanlış bilgiler içermediğini düşündükleri ortaya çıkmıştır. Grafik sunum formatlarının belirli bir standarda oturtulmamasının, yatırımcıların güven duygularını istismar edici kimseler için bir firsat oluşturduğu görülmüştür.

Demir ve Yağcılar (2009), çalışmalarında 2000-2006 döneminde BIST'de işlem gören 13 bankanın aylık getirileri ve bu getiriyi etkileyen makroekonomik değişkenlere karşı duyarlılığı ve getirileri açıklama gücü Arbitraj Fiyatlama Modeli kullanılarak incelenmiştir. Çalışma sonucunda, BIST 100 endeksinin bankaların hisse senedi getirileri üzerinde büyük ölçüde etkili 
olduğu, hisse senedi getirilerini etkileyen faktörlerin analizinde arbitraj fiyatlama modelinin geçerli bir model olduğu sonucuna varılmıştır.

Yüksel (2009), yatırımcıların göstermiş olduğu ortak eğilimlerin belirlenmesi amaciyla yaptığı araştırma sonucunda; ekonomi, finans teori ve modellerinin bir süre sonra eksik kaldığ 1 ve bireylerin aslında rasyonel hareket etmedikleri anlaşılmıştır.

Otluoğlu (2009)'nun, aşırı güven davranışının BIST'deki yatırımcılar üzerindeki etkisini incelediği çalışma sonucunda, fiyatlardaki volatilitenin nedeninin aşırı güven eğilimi olmadığı sonucuna varılmıştır. Negatif getirilerinin sebep olduğu volatilitenin hem miktar hem de süre açısından pozitif getirilerinin sebep olduğu volatiliteden farklı olmadığ 1 sonucu da bunu destekler niteliktedir.

Şenkesen (2009), yatırımcı duyarlılığının Türk tahvil verimi üzerindeki etkisi üzerine bir çalışma yapmıştır. Sonuç olarak makroekonomik parametrelerden çok, uluslararası likidite koşulları ile yatırımcı duyarlılığının Türkiye'de tahvil verimleri üzerinde etkili olduğu görülmüştür.

Oran vd. (2010), çalışmalarında Türkiye'de mevcut bir takım algısal sapmalar anket yöntemiyle incelenmiştir. Verilerin analizi sonucu katılımcıların basit çıpalama algı yanılgısı incelendiğinde anlamlı sonuçlara ulaşılamamıştır. Referans noktası etkisi ise güvenli bir alternatif ile desteklendiğinde teşvik edici sonuçlar doğurduğu; yanlı olasılık değerlendirme algı hatasının da kumarbaz yanılgıs1 yönünde ağır bastığı görülmüştür. Risk eğiliminin bireysel kararlar üzerinde oldukça etkili olduğu sonucuna varılmıştır.

Sönmez (2010), aşırı tepki hipotezini incelemek ve BIST'deki etkisini tespit etmek amacıyla yaptı̆̆ çalışma sonucunda, hipotezin BIST'de kısa vadede var olduğu görülmüştür. BIST' nin zayıf formda etkin olmadığını, yatırımcıların kısa vadeli zıtlık stratejileri uygulayarak büyük kazançlar sağlayabileceği öngörülmüştür.

Kahyaoğlu (2011) çalışmasında, kadın ve erkek yatırımcıların risk algılarına etki eden psikolojik ve duygusal faktörler arasındaki farklılıkları incelemiş, kadın ve erkek yatırımcılar arasında istatistiksel olarak anlamlı farklılıklara ulaşılmıştır. Ayrıca, risk algılarına bakıldığında kadın yatırımcıların erkeklere oranla yüksek olduğu görülmüştür. Bir takım psikolojik ve duygusal faktörlerden etkilenen risk algısının, kadın ve erkek yatırımcılar arasında etkilenme düzeyleri açısından farklılıkların oluşturabileceği görüşü ileri sürülebilmektedir.

Doğukanlı ve Ergün (2011) çalışmalarında BIST'nin beş farklı endeksinde ve Aşırı Tepki Hipotezinin ve zıtlık stratejilerinin anormal derecede 
yüksek gelir elde etmede işe yarayıp yaramadığını araştırmışlardır. Analiz sonucunda BIST Ulusal 30 endeksi dıșındaki endekslerde Aşırı Tepki Hipotezinin ve zitlık stratejilerinin faydalı olduğunu destekler bulgulara rastlanmış, BIST'nin zayıf formda daha etkin olmadığı sonucuna varılmıştır.

Wang vd. (2011) yaptıkları çalışmada kadın ve erkekleri varlık yatırımları konusunda karşılaştırmıştır. Çalışma sonucunda kadınların risk algılarının erkeklerden daha fazla olduğu sonucuna ulaşılmışırı. Ayrıca getirisi sabit ve getirisi yüksek, popüler, değerli menkul kıymetler üzerindeki değerlendirmede her iki cins için de farklı risk algılarına rastlanmamıştır.

Bir diğer değerlendirme, kadınların erkeklere oranla antika, altın ve sanat yatırımları daha az riskli buldukları tespit edilmiştir.

Çevik (2012), BIST'de zayıf etkinliğin geçerlilik düzeyini sektörel bazda ele aldığı çalışmasında, sektörlere ait oynaklık serilerinde uzun hafiza faktörünün rol oynadığı belirlenmiştir. Bu durum, BIST'de oynaklığın önceki değerlerinden etkilendiğini dolayısıyla tahmin edilebilir bir yapı sergilediğini ve BIST’nin zayıf formda etkinliğin söz konusu olmadığını göstermektedir.

Ege vd. (2012) çalışmalarında, etkin piyasalar hipotezinin teorik ve ampirik şekilde test edilmesi amacıyla hisse senedi getirileri ve endeks getirilerinin davranışsal özelliklerini araştırmışlardır. Analiz sonucunda incelenen dönem içerisinde ocak ayı anomalisine rastlanılmış ve bu anomalilerin sebepleri açıklanmaya çalışılmıştır.

Bayar (2012), küresel finansal krizin BIST 'de yatırım yapan bireysel yatırımcılar üzerindeki etkilerini davranışsal perspektiften incelemek ve davranışsal finansın ortaya koyduğu bazı önermelerin finansal kriz sürecinde geçerliliğini sınamak amacıyla bir çalışma yapmıştır. Çalışma sonucunda küresel finansal krizin, yatırımcıların yaklaşı yarısının psikolojisini ve hisse senedi piyasasına olan güvenlerini olumsuz yönde etkilediği geleceğe ilişkin bir takım olumsuz düşüncelere kapılmaya başladıkları sonucuna varılmıştır.

Böyükaslan (2012)'ın bireysel yatırımcıların yatırım kararları üzerine etki eden faktörleri ortaya koymak amacıyla yaptığı çalışma sonucunda, yatırımcıların karar verirlerken büyük ölçüde davranışsal finans eğilimlerinin etkisinde kaldıklarını göstermiştir.

Kandır vd. (2013) yaptıkları çalışmada yatırım ortaklıkları iskontosu ve tüketici güven endeksi arasındaki ilişkiyi incelemişlerdir. Analiz sonucunda değişkenler arasında uzun vadeli bir ilişkinin varlığı saptanmıştır.

Gümüş vd. (2013), Türkiye ve Azerbaycan'daki yatırımcıların yatırım kararlarına etki eden faktörleri tespit etmek amacıyla yaptıkları çalışmada, 
yatırımcıların bazı kararları üzerinde, bir takım demografik özelliklerin farklılaşmaya neden olduğu görülmüştür.

Küden (2014), bireysel yatırımcıların yatırımcı profilini ortaya koymak için yaptığı çalışmada, psikolojik önyargılar, bireysel yatırımcıların tercihlerini ve davranışlarını etkilediğini göstermiştir. Yatırımcıların rasyonel olmayan davranışlar sergilemelerinin nedeninin bilgi yetersizliği değil de psikolojik önyargılar olduğu anlaşılmıştır.

Sevim ve Akkoç (2007), BIST'de düşük fiyat etkisini test etmek amacıyla bir çalışma yapmış, sonuç olarak BIST'de düşük fiyat etkisinin olmadığ yüksek fiyatlı hisse senetlerinin yatırımcılarına piyasanın üzerinde bir getiri sağladığı görülmüştür.

Küçük (2014), çalışmasında bireylerin yatırım kararlarında psikolojik ve sosyolojik etkilerinin etkisini ölçmek amacıyla bir çalışma yapmışlardır. Sonuç olarak, davranışsal finansın yatırım kararlarını büyük ölçüde etkilediği sonucuna varılmıştır.

Kök ve Uyğur (2014) çalışmalarında hisse senedi getirilerini etkileyen faktörleri arbitraj fiyatlama modeli çerçevesinde incelemişlerdir. Çalışma sonucunda, ele alınan değişkenlerdeki ani değişimler ve bunların etkilediği başka değişkenlere etki edebilecek muhtemel değişimlerin olduğu yönünde bir takım verilere rastlanmıştır.

Choi vd. (2015), Güney Kore ve ABD piyasalarında momentum staretejisini inceledikleri çalışmalarında, geçmiş kazanan portföylerin geçmiş kaybeden portföylere göre daha iyi performans sergileyerek bir momentum stratejisinin anomaliye sebep olduğu sonucuna varmışlardır.

Aldemir (2015), bireysel yatırımcıların yatırım kararları üzerinde etki eden psikolojik eğilimlerin etkisini ölçmek amacıyla yaptığı çalışmada; bireyler için uygun bir yatırım politikasının belirlenebilmesi için yatırım yapma amaçlarının, riske girme durumunun, gelirin, yaşının ve mesleğinin bilinmesinin önemi olduğu ve finansal risk toleransı, eğitim durumu, meslek, kişilik özelliği, geliri gibi faktörlerin bireysel yatırım davranışları üzerinde önemli ölçüde etkisinin olduğu sonucuna varılmıştır.

Aytekin (2015) çalışmasında, Van ilinde yaşayan bireysel yatırımcıların finansal yatırım kararlarında etkili olan faktörlerin davranışsal finans açısından ele alınması amacıyla bir çalışma yapmışlardır. Sonuç olarak Van'da ikamet eden bireysel yatırımcıların, yatırım kararları üzerinde ekonomik olmayan etkenlerin etkili olduğunu, yatırımcıların davranışsal finans eğilimlerinden etkilendikleri sonucuna varılmıştır. 
Aslan (2016)'ın bireysel yatırımcıların yatırım kararlarını belirlemek amacıyla yaptığı çalışmada, yatırımcıların karar alırlarken psikolojik ve sosyal faktörlerin etkisinde kaldıkları, düşük portföy sayısının fazlalığı sebebiyle çok fazla riske girdikleri sonucuna varılmıştır.

Alpdündar (2016) çalışmasında bireylerin sigorta yaptırma kararlarında etkin olan davranış şekillerini davranışsal finans eğilimleri kapsamında incelenmiştir. Çalışması sonucunda, bireylerin sigorta sektörüyle ilgili alınan kararlarda rasyonaliteden uzaklaşıp duygularının ve diğer bilişsel kısıtlarının etkisinde kaldığı sonucuna ulaşılmıştır.

\section{VERI VE YÖNTEM}

Çalışmanın ana kütlesini bireysel yatırımcılar oluştururken, örneklemini ise Erzincan ili oluşturmaktadır. Bu amaçla, verilerin elde edilmesinde anket yöntemi kullanılmıştır.

Anket verileri 2017 yılı Temmuz-Eylül ayları arasında toplam 390 bireysel yatırımcıya uygulanarak elde edilmiştir. Anket sorularının güvenilirliği, Cronbach alfa katsayısı ile kontrol edilmiştir. Yapılan analiz sonucu, Cronbach alfa değerlerinin 0,936 çıtığ görülmüştür.

Cronbach alfa katsayısının $0.70 \leq \alpha<0.90$ arasında bulunması durumunda ölçeğin güvenirliği iyi olarak kabul edilmektedir (Kılıç, 2016: 48). Basit tesadüfi örneklem yöntemiyle elde edilen anket verileri SPSS 22.0 istatistik programı kullanılarak ki-kare testiyle analiz edilmiştir. Analize yönelik hipotezler bu doğrultuda oluşturulmuş olup analize dâhil edilecektir.

Araştırma hipotezleri ki-kare ile test edilirken oluşan tablolarda, toplam hücre sayısının \%20'sinden fazlasında 5'ten küçük frekansa rastlanmıştır. Ankette yer alan soruların bazı seçeneklerine düşük sayıda yanıt verilmesinden kaynaklanan bu durum ki-kare değerinin okunmasına imkân vermemektedir.

Ki- kare analizinin geçerli olabilmesi için, gözlenen küçük frekanslı iki veya daha fazla satır-sütun değerleri birleştirilerek beklenen değerlerin büyük olmaları sağlanmaktadır. Düzeltme analizi yapıldıktan sonra geçerli ki-kare değerleri elde edilmiştir (Güngör ve Bulut, 2008: 86).

Pearson ki-kare değerinin 0,05 'ten küçük çıkması durumunda, değiş̧kenler arasında anlamlı bir ilişkinin olduğu kabul edilmektedir. Değerin 0,05 'ten büyük çıkması durumunda ise değişkenler arasında anlamlı bir ilişkiden söz edilememektedir. 
KAÜiiBFD 9(18), 2018: 391-420

\section{BULGULAR}

Tablo 1: Demografik Özelliklere İlişkin Betimsel İstatistik Sonuçları

\begin{tabular}{|c|c|c|c|c|c|}
\hline & Yanıtlar & Frekans & Yüzde & Geçerli Yüzde & $\begin{array}{c}\text { Kümülatif } \\
\text { Yüzde }\end{array}$ \\
\hline \multirow{3}{*}{. } & Erkek & 248 & 63,6 & 63,6 & 63,6 \\
\hline & Kadın & 142 & 36,4 & 36,4 & 100,0 \\
\hline & Toplam & 390 & 100,0 & 100,0 & \\
\hline \multirow{3}{*}{ 总 } & Evli & 262 & 67,2 & 67,2 & 67,2 \\
\hline & Bekâr & 128 & 32,8 & 32,8 & 100,0 \\
\hline & Toplam & 390 & 100,0 & 100,0 & \\
\hline \multirow{11}{*}{$\stackrel{\pi}{\pi}$} & $21-25$ & 54 & 13,8 & 13,8 & 13,8 \\
\hline & $26-30$ & 75 & 19,2 & 19,2 & 33,1 \\
\hline & $31-35$ & 94 & 24,1 & 24,1 & 57,2 \\
\hline & $36-40$ & 54 & 13,8 & 13,8 & 71,0 \\
\hline & $41-45$ & 49 & 12,6 & 12,6 & 83,6 \\
\hline & $46-50$ & 26 & 6,7 & 6,7 & 90,3 \\
\hline & $51-55$ & 24 & 6,2 & 6,2 & 96,4 \\
\hline & $56-60$ & 5 & 1,3 & 1,3 & 97,7 \\
\hline & $61-65$ & 6 & 1,5 & 1,5 & 99,2 \\
\hline & 65 ve üzeri & 3 &, 8 &, 8 & 100,0 \\
\hline & Toplam & 390 & 100,0 & 100,0 & \\
\hline \multirow{6}{*}{ 正 } & Okuryazar & 4 & 1,0 & 1,0 & 1,0 \\
\hline & İlk-orta & 39 & 10,0 & 10,0 & 11,0 \\
\hline & Lise & 85 & 21,8 & 21,8 & 32,8 \\
\hline & Ön Lisans-lisans & 211 & 54,1 & 54,1 & 86,9 \\
\hline & Lisans Üstü & 51 & 13,1 & 13,1 & 100,0 \\
\hline & Toplam & 390 & 100,0 & 100,0 & \\
\hline \multirow{6}{*}{ 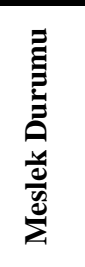 } & Kamuda Ücretli & 127 & 32,6 & 32,6 & 32,6 \\
\hline & $\begin{array}{c}\text { Özel Sektörde } \\
\text { Ücretli }\end{array}$ & 150 & 38,5 & 38,5 & 71,0 \\
\hline & Serbest Meslek & 61 & 15,6 & 15,6 & 86,7 \\
\hline & Ev Hanımı & 12 & 3,1 & 3,1 & 89,7 \\
\hline & Diğger & 40 & 10,3 & 10,3 & 100,0 \\
\hline & Toplam & 390 & 100,0 & 100,0 & \\
\hline
\end{tabular}

Tablo 1'e göre, ankete katılanların \%63,6'sının erkek, \%36,4'ünün ise kadın katılımcılardan oluştuğu, bunların \%67,2'sinin evli, \%32,8'inin bekâr olduğu anlaşılmaktadır. Yaş aralıklarına bakıldığında 21-45 yaş arası; eğitim durumunun ise lisans-ön lisans mezunu katılımcıların yoğunluk gösterdiği görülmektedir. Katılımcıların meslek gruplarına değerlendirilmesi sonucunda \%38,5 oranla özel sektör çalışanları, \%32,6 ile kamuda ücretli çalışanların 
yoğunlukta olduğu görülmektedir. Serbest meslek erbapları, ev hanımı ve diğer meslek çalışanlarının düşük oranlarda olduğu anlaşılmaktadır.

Tablo 2: Finansal Özelliklere İlişkin Betimsel İstatistik Sonuçları

\begin{tabular}{|c|c|c|c|c|c|}
\hline & Yanitlar & Frekans & Yüzde & Geçerli Yüzde & $\begin{array}{c}\text { Kümülatif } \\
\text { Yüzde }\end{array}$ \\
\hline \multirow{6}{*}{ 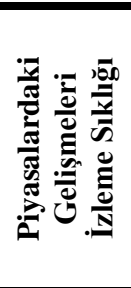 } & İzlemiyorum & 152 & 39,0 & 39,0 & 39,0 \\
\hline & Her gün & 61 & 15,6 & 15,6 & 54,6 \\
\hline & Haftalık & 70 & 17,9 & 17,9 & 72,6 \\
\hline & Aylik & 78 & 20,0 & 20,0 & 92,6 \\
\hline & Y1ll1k & 29 & 7,4 & 7,4 & 100,0 \\
\hline & Toplam & 390 & 100,0 & 100,0 & \\
\hline \multirow{6}{*}{ 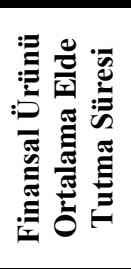 } & 1 hafta & 51 & 13,1 & 13,1 & 13,1 \\
\hline & 1 ay & 46 & 11,8 & 11,8 & 24,9 \\
\hline & $1 \mathrm{y} 1 \mathrm{l}$ & 101 & 25,9 & 25,9 & 50,8 \\
\hline & $2-5 \mathrm{y} 1 \mathrm{l}$ & 127 & 32,6 & 32,6 & 83,3 \\
\hline & 6 ve üzeri & 65 & 16,7 & 16,7 & 100,0 \\
\hline & Toplam & 390 & 100,0 & 100,0 & \\
\hline \multirow{6}{*}{ 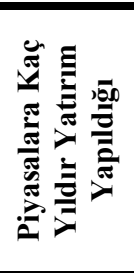 } & $0-1$ & 120 & 30,8 & 30,8 & 30,8 \\
\hline & $2-5$ & 161 & 41,3 & 41,3 & 72,1 \\
\hline & $6-10$ & 74 & 19,0 & 19,0 & 91,0 \\
\hline & $11-20$ & 20 & 5,1 & 5,1 & 96,2 \\
\hline & 21 ve üzeri & 15 & 3,8 & 3,8 & 100,0 \\
\hline & Toplam & 390 & 100,0 & 100,0 & \\
\hline \multirow{6}{*}{ 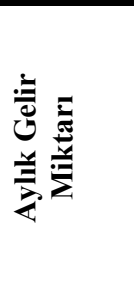 } & $1-1000$ & 29 & 7,4 & 7,4 & 7,4 \\
\hline & $1001-2000$ & 66 & 16,9 & 16,9 & 24,4 \\
\hline & $2001-4000$ & 202 & 51,8 & 51,8 & 76,2 \\
\hline & $4001-6000$ & 64 & 16,4 & 16,4 & 92,6 \\
\hline & 6000 ve üzeri & 29 & 7,4 & 7,4 & 100,0 \\
\hline & Toplam & 390 & 100,0 & 100,0 & \\
\hline
\end{tabular}

Tablo 2'ye göre; anket katılımcılarının finans piyasalarındaki gelişmeleri izleme sıklığ 1 incelendiğinde katılımcıların \%39,0 oranında piyasalardaki gelişmeleri izlemedikleri görülmektedir. Katılımcıların finansal ürünleri ortalama elde tutma süreleri incelendiğinde bu sürenin 1-5 yıl arasında yoğunlaştığı görülmektedir. Katılımcıların aylık gelir durumlarına bakıldığında, \%51,8'inin yani büyük çoğunluğunun 2001-4000 TL gelire sahip oldukları görülmektedir. Diğer gelir düzeylerinin birbirlerine yakın seviyede olduğu gözlenmiştir. Yatırımcıların finans piyasalarına kaç yıldır yatırım yaptıklarına bakıldığında genel itibariyle 0-5 yıl arası yatırım yapanların çoğunlukta olduğu 
görülmektedir.

\section{Aşırı İyimserlik Hipotezleri}

1. Yatırımcıların aylık gelir miktarlarıyla aşırı iyimserlik eğilimi arasında anlamlı bir ilişki vardır.

2. Yatırımcıların finans piyasalarındaki gelişmeleri izleme sıklı̆ğ ile aşırı iyimserlik eğilimi arasında anlamlı bir ilişki vardır.

3. Yatırımcıların finansal yatırım araçlarına kaç yıldır yatırım yaptıkları ile aşırı iyimserlik eğilimi arasında anlamlı bir ilişki vardır.

4. Yatırımcıların finansal araçları elde tutma süreleri ile aşırı iyimserlik eğilimi arasında anlamlı bir ilişki vardır.

Tablo 3: Aşırı İyimserlik Eğiliminin Analizi

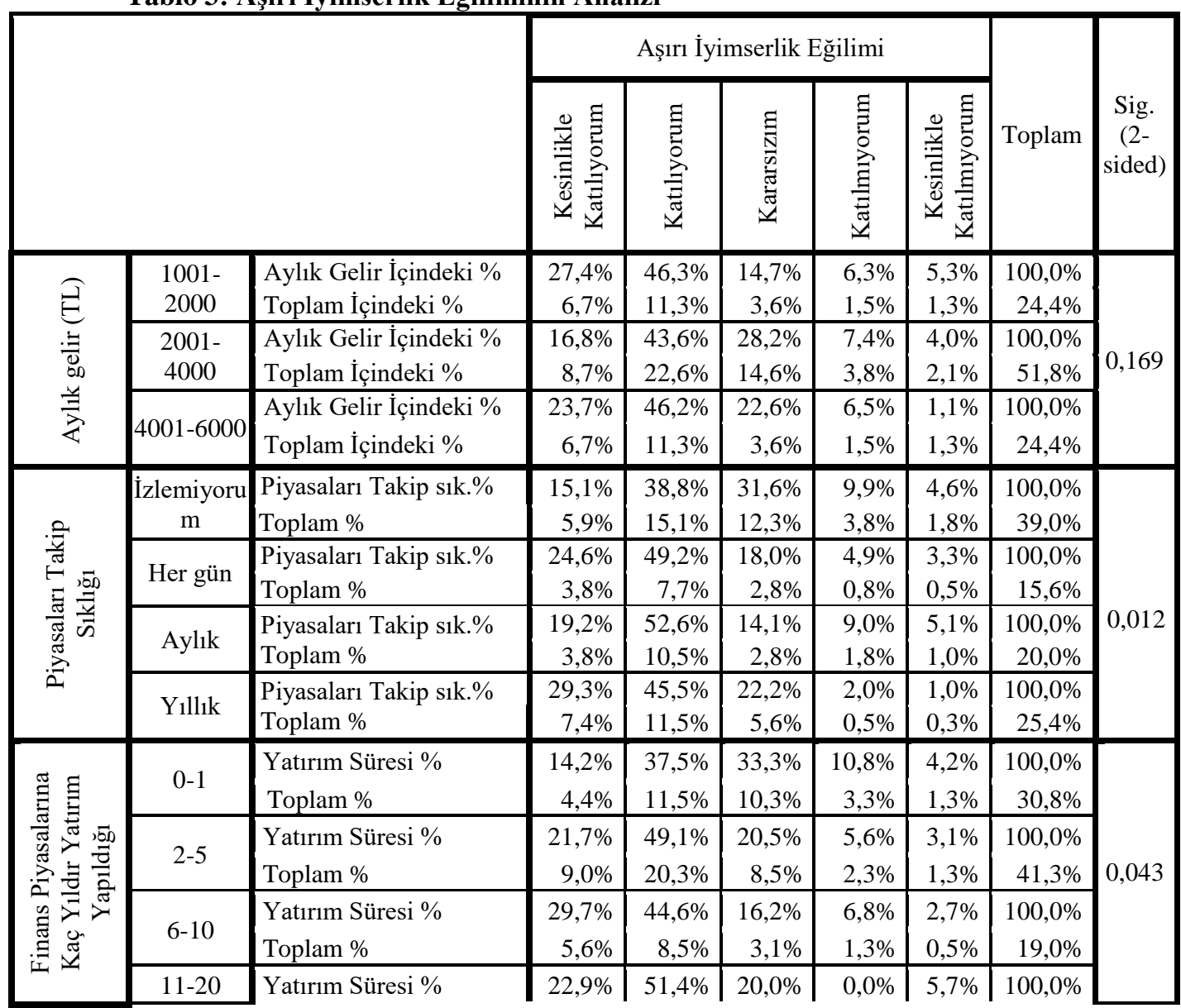


KAÜiIBFD 9(18), 2018: 391-420

\begin{tabular}{|c|c|c|c|c|c|c|c|c|c|}
\hline & & Toplam \% & $2,1 \%$ & $4,6 \%$ & $1,8 \%$ & $0,0 \%$ & $0,5 \%$ & $9,0 \%$ & \\
\hline \multirow{6}{*}{ 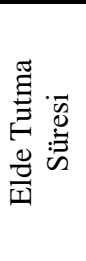 } & \multirow[t]{2}{*}{1 Hafta } & Elde Tutma Süresi \% & $17,1 \%$ & $43,4 \%$ & $23,7 \%$ & $11,2 \%$ & $4,6 \%$ & $100,0 \%$ & \multirow{6}{*}{0,002} \\
\hline & & Toplam \% & $6,7 \%$ & $16,9 \%$ & $9,2 \%$ & $4,4 \%$ & $1,8 \%$ & $39,0 \%$ & \\
\hline & \multirow{2}{*}{1 Ay } & Elde Tutma Süresi \% & $16,2 \%$ & $43,2 \%$ & $31,5 \%$ & $7,2 \%$ & $1,8 \%$ & $100,0 \%$ & \\
\hline & & Toplam \% & $4,6 \%$ & $12,3 \%$ & $9,0 \%$ & $2,1 \%$ & $0,5 \%$ & $28,5 \%$ & \\
\hline & \multirow{2}{*}{ 2-5 Y1l } & Elde Tutma Süresi \% & $29,9 \%$ & $48,0 \%$ & $16,5 \%$ & $1,6 \%$ & $3,9 \%$ & $100,0 \%$ & \\
\hline & & Toplam \% & $9,7 \%$ & $15,6 \%$ & $5,4 \%$ & $0,5 \%$ & $1,3 \%$ & $32,6 \%$ & \\
\hline
\end{tabular}

Tablo 3 sonucuna göre, aşırı iyimserlik eğilimi ile yatırımcıların aylık gelirleri arasında anlamlı bir ilişkinin olmadığı ortaya çıkmıştır. Pearson anlamlılık değeri 0,169 olduğundan hipotez reddedilir.

Yatırımcıların finans piyasalarındaki gelişmeleri izleme sıklığ iyimserlik eğilimi arasındaki ilişkiye bakıldığında iki değişken arasında anlamlı bir ilişki olduğu görülmektedir. P değerinin 0,05 'ten kü̧̈ük olması hipotezin kabul edildiği anlamına gelmektedir. Tablo verilerine göre, piyasaları hiç takip etmeyen yatırımcılar, aşırı iyimserlik eğilimini \%53,9 oranında yansıtmakta, "her gün" takip edenler $\% 73,8$ oranında, "aylık" takip edenler $\% 71,8$ oranında, "yıllık" takip edenler ise aşırı iyimserlik eğilimini \%74,8 oranında yansıtmaktadırlar. Tablodan elde edilen sonuçlara göre yatırımcıların finans piyasalarına yatırım yapma süreleri ile aşırı iyimserlik eğilimi arasında anlamlı bir ilişki bulunduğu ortaya çıkmıştır. $P$ değeri 0,05 ’ten küçük olduğu için $(0,043)$ hipotez kabul edilmektedir. Buna göre; "0-1 y1l” yatırım yapanların $\% 51,7$ 'si, “2-5 yil” yatırım yapanların \%70,8'i, "6-10 y11” yatırım yapanların $\% 74,3$ 'ü, "11-20 yıl”" arasında yatırım yapanların ise \%74,3'si aşırı iyimserlik eğilimi göstermektedirler. Tabloya göre, yatırımcıların finansal araçları elde tuttukları süre ile aşırı iyimserlik eğilimi arasında anlamlı bir ilişki vardır. Buna göre finansal ürünleri 1 hafta elde tutanların $\% 60,5$ 'i, 1 ay tutanların $\% 59,4$ 'ü, 2-5 yıl tutanların ise \% 77,9 'u aşırı iyimserlik eğilimi göstermektedirler.

\section{Mevcudiyet Eğiliminin Hipotezleri}

1. Yatırımcıların aylık gelirleri ile mevcudiyet eğilimi arasında anlamlı bir ilişki vardır.

2. Yatırımcıların finans piyasalarındaki gelişmeleri izleme sıklı̆ğ ile mevcudiyet eğilimi arasında anlamlı bir ilişki vardır.

3. Yatırımcıların finansal yatırım araçlarına kaç yıldır yatırım yaptıkları ile mevcudiyet eğilimi arasında anlamlı bir ilişki vardır.

4. Yatırımcıların finansal araçları elde tutma süreleri ile mevcudiyet eğilimi arasında anlamlı bir ilişki vardır. 
KAÜiiBFD 9(18), 2018: 391-420

Tablo 4: Mevcudiyet Eğiliminin Analizi

\begin{tabular}{|c|c|c|c|c|c|c|c|c|c|}
\hline & & & \multicolumn{5}{|c|}{ Mevcudiyet Eğilimi } & \multirow[b]{2}{*}{ Toplam } & \multirow[b]{2}{*}{$\begin{array}{c}\text { Sig. } \\
(2- \\
\text { sided })\end{array}$} \\
\hline & & & 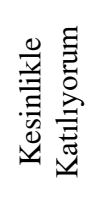 & 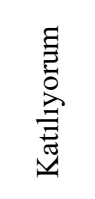 & 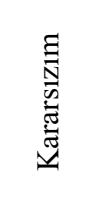 & 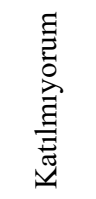 & 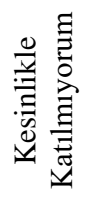 & & \\
\hline \multirow{6}{*}{ 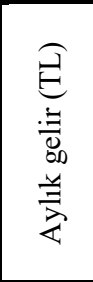 } & \multirow{2}{*}{$1001-2000$} & Aylık gelir İçindeki \% & $18,9 \%$ & $37,9 \%$ & $28,4 \%$ & $9,5 \%$ & $5,3 \%$ & $100,0 \%$ & \multirow{6}{*}{0,028} \\
\hline & & Toplam İçindeki \% & $4,6 \%$ & $9,2 \%$ & $6,9 \%$ & $2,3 \%$ & $1,3 \%$ & $24,4 \%$ & \\
\hline & \multirow{2}{*}{$2001-4000$} & Aylık gelir İçindeki \% & $11,9 \%$ & $45,0 \%$ & $34,7 \%$ & $4,5 \%$ & $4,0 \%$ & $100,0 \%$ & \\
\hline & & Toplam İçindeki \% & $6,2 \%$ & $23,3 \%$ & $17,9 \%$ & $2,3 \%$ & $2,1 \%$ & $51,8 \%$ & \\
\hline & \multirow{2}{*}{$4001-6000$} & Aylık gelir İçindeki \% & $10,8 \%$ & $60,2 \%$ & $21,5 \%$ & $6,5 \%$ & $1,1 \%$ & $100,0 \%$ & \\
\hline & & Toplam İçindeki \% & $2,6 \%$ & $14,4 \%$ & $5,1 \%$ & $1,5 \%$ & $0,3 \%$ & $23,8 \%$ & \\
\hline \multirow{6}{*}{ 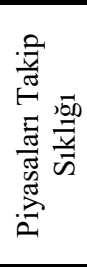 } & \multirow{2}{*}{ İzlemiyorum } & Piyasaları Takip sık.\% & $12,5 \%$ & $32,2 \%$ & $41,4 \%$ & $8,6 \%$ & $5,3 \%$ & $100,0 \%$ & \multirow{6}{*}{0,001} \\
\hline & & Toplam \% & $4,9 \%$ & $12,6 \%$ & $16,2 \%$ & $3,3 \%$ & $2,1 \%$ & $39,0 \%$ & \\
\hline & \multirow{2}{*}{ Aylik } & Piyasaları Takip sık.\% & $12,8 \%$ & $59,0 \%$ & $23,1 \%$ & $2,6 \%$ & $2,6 \%$ & $100,0 \%$ & \\
\hline & & Toplam \% & $2,6 \%$ & $11,8 \%$ & $4,6 \%$ & $0,5 \%$ & $0,5 \%$ & $20,0 \%$ & \\
\hline & \multirow{2}{*}{ Y1llik } & Piyasaları Takip sık.\% & $14,4 \%$ & $55,0 \%$ & $22,5 \%$ & $5,6 \%$ & $2,5 \%$ & $100,0 \%$ & \\
\hline & & Toplam \% & $5,9 \%$ & $22,6 \%$ & $9,2 \%$ & $2,3 \%$ & $1,0 \%$ & $41,0 \%$ & \\
\hline \multirow{6}{*}{ 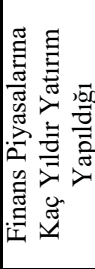 } & \multirow{2}{*}{$0-1$} & Yatırım Süresi \% & $8,6 \%$ & $34,3 \%$ & $42,1 \%$ & $9,3 \%$ & $5,7 \%$ & $100,0 \%$ & \multirow{6}{*}{0,000} \\
\hline & & Toplam \% & $3,1 \%$ & $12,3 \%$ & $15,1 \%$ & $3,3 \%$ & $2,1 \%$ & $35,9 \%$ & \\
\hline & \multirow{2}{*}{$2-5$} & Yatırım Süresi \% & $16,8 \%$ & $51,6 \%$ & $24,8 \%$ & $4,3 \%$ & $2,5 \%$ & $100,0 \%$ & \\
\hline & & Toplam \% & $6,9 \%$ & $21,3 \%$ & $10,3 \%$ & $1,8 \%$ & $1,0 \%$ & $41,3 \%$ & \\
\hline & \multirow{2}{*}{$6-10$} & Yatırım Süresi \% & $14,6 \%$ & $58,4 \%$ & $20,2 \%$ & $4,5 \%$ & $2,2 \%$ & $100,0 \%$ & \\
\hline & & Top & $3,3 \%$ & $13,3 \%$ & $4,6 \%$ & $1,0 \%$ & $0,5 \%$ & $22,8 \%$ & \\
\hline \multirow{8}{*}{ 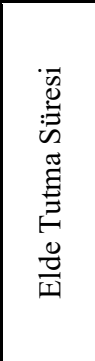 } & \multirow{2}{*}{1 Ay } & Elde Tutma Süresi \% & $10,3 \%$ & $22,7 \%$ & $43,3 \%$ & $15,5 \%$ & $8,2 \%$ & $100,0 \%$ & \multirow{8}{*}{0,000} \\
\hline & & Toplam \% & $2,6 \%$ & $5,6 \%$ & $10,8 \%$ & $3,8 \%$ & $2,1 \%$ & $24,9 \%$ & \\
\hline & \multirow{2}{*}{$1 \mathrm{Y}_{1}$} & Elde Tutma Süresi \% & $18,8 \%$ & $33,7 \%$ & $32,7 \%$ & $9,9 \%$ & $5,0 \%$ & $100,0 \%$ & \\
\hline & & Toplam \% & $4,9 \%$ & $8,7 \%$ & $8,5 \%$ & $2,6 \%$ & $1,3 \%$ & $25,9 \%$ & \\
\hline & \multirow{2}{*}{ 2-5 Yil } & Elde Tutma Süresi \% & $16,5 \%$ & $59,1 \%$ & $19,7 \%$ & $2,4 \%$ & $2,4 \%$ & $100,0 \%$ & \\
\hline & & Toplam \% & $5,4 \%$ & $19,2 \%$ & $6,4 \%$ & $0,8 \%$ & $0,8 \%$ & $32,6 \%$ & \\
\hline & \multirow{2}{*}{6 ve üzeri } & Elde Tutma Süresi \% & $15,4 \%$ & $53,8 \%$ & $23,1 \%$ & $6,2 \%$ & $1,5 \%$ & $100,0 \%$ & \\
\hline & & Toplam \% & $2,6 \%$ & $9,0 \%$ & $3,8 \%$ & $1,0 \%$ & $0,3 \%$ & $16,7 \%$ & \\
\hline
\end{tabular}

Tablo 4'te, yatırımcıların aylık gelirleri ile mevcudiyet eğilimi arasında pozitif yönlü bir ilişkinin olduğu görülmektedir. Buna göre; aylık geliri 10012000 TL arasında olanların \%56,8'i, 2001-4000 TL arasında olanların \%56,9'u, 4001-6000 TL arasında olanların ise \%80'i mevcudiyet eğilimi göstermektedirler. Tabloya göre, katılımcıların piyasaları takip sıklığı ile 
mevcudiyet eğilimi arasında da anlamlı bir ilişkiden söz edilebilmektedir. Bu durum hipotezin kabul edildiği anlamına gelmektedir. Tabloya göre; finans piyasalarını hiç takip etmeyen katılımcıların \%44,7'si, aylık izleyenlerin $\% 68,9$ 'u, yıllık izleyenlerin ise \%79,3’ü mevcudiyet eğilimi göstermektedir. Tablodan da anlaşıldığı üzere yatırım yapma süreleri ile mevcudiyet eğilimi arasındaki ilişki $\mathrm{P}=0,000$ düzeyinde anlamlı bulunmakta ve hipotez kabul edilmektedir. Buna göre, 0-1 y1l arası yatırım yapanların \%42,9'u, 2-5 yıl arası yatırım yapanların \%68,4'ü, 6-10 yıl aras1 yatırım yapanların \%73'ü mevcudiyet eğilimi göstermektedirler. Yatırımcıların finansal araçları elde tutma süreleri ile mevcudiyet eğilimi arasındaki ilişki durumunu gösteren yukarıdaki tabloya göre iki değişken arasında anlamlı bir ilişkinin varlığından söz etmek mümkündür. Bu durumda finansal araçları " 1 ay" ellerinde tutanların \%33'ü, "1 y1l” elde tutanların\%52,5'i, "2-5 y1l” tutanların \%75,6's1, "6 ve üzeri y1l” tutanların ise \%69,2'si mevcudiyet eğilimi göstermektedirler.

\section{Temsil Etme Eğiliminin Hipotezleri}

1. Yatırımcıların aylık gelir miktarlarıyla temsil etme eğilimi arasında anlamlı bir ilişki vardır.

2. Yatırımcıların finans piyasalarındaki gelişmeleri takip sıklığı ile temsil etme eğilimi arasında anlamlı bir ilişki vardır.

3. Yatırımcıların finansal yatırım araçlarına kaç yıldır yatırım yaptıkları ile temsil etme eğilimi arasında anlamlı bir ilişki vardır.

4. Yatırımcıların finansal araçları elde tutma süreleri ile temsil etme eğilimi arasında anlamlı bir ilişki vardır.

Tablo 5: Temsil Etme Eğiliminin Analizi

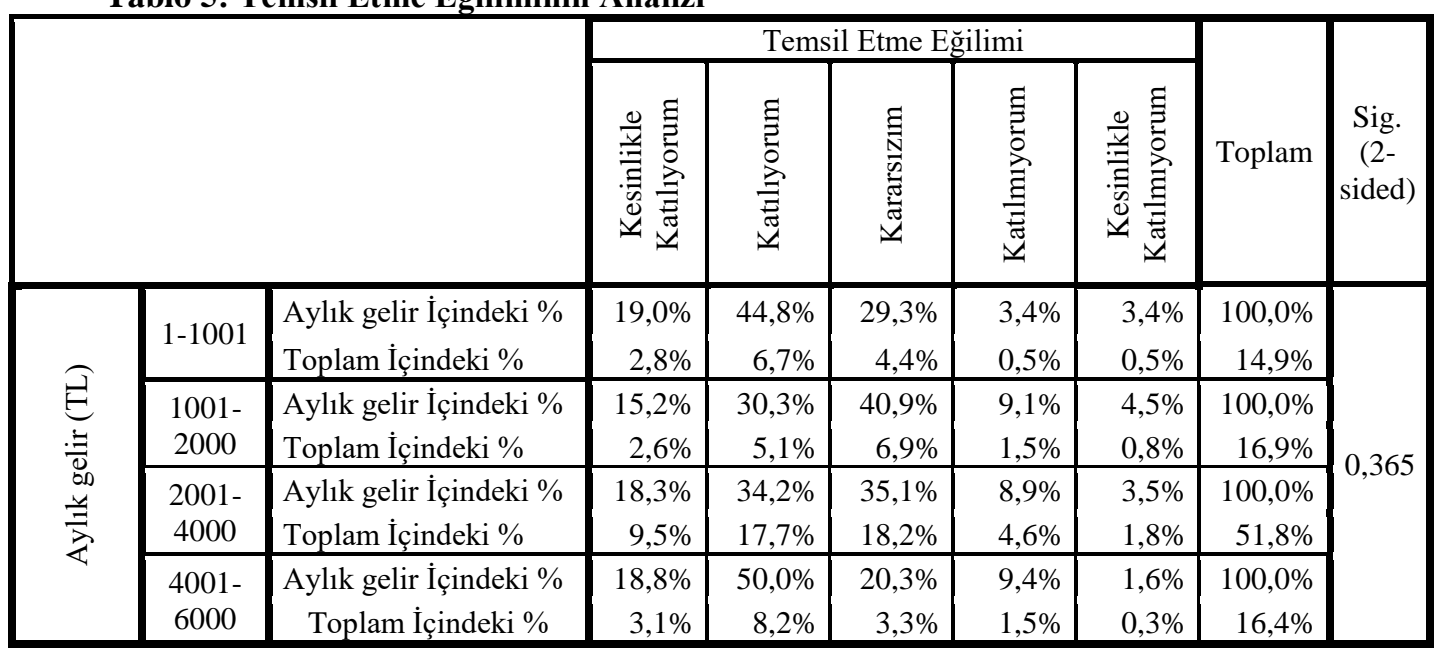


KAÜiiBFD 9(18), 2018: 391-420

Tablo 5 (Devam): Temsil Etme Eğiliminin Analizi

\begin{tabular}{|c|c|c|c|c|c|c|c|c|c|}
\hline \multirow{5}{*}{ 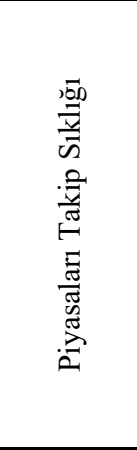 } & İzlemiyorum & $\begin{array}{l}\text { Piyasaları Takip Sıklı̆̆ı\% } \\
\text { Toplam \% }\end{array}$ & $\begin{array}{r}14,5 \% \\
5,6 \% \\
\end{array}$ & $\begin{array}{l}26,3 \% \\
10,3 \% \\
\end{array}$ & $\begin{array}{l}42,8 \% \\
16,7 \%\end{array}$ & $\begin{array}{r}11,8 \% \\
4,6 \% \\
\end{array}$ & $\begin{array}{l}4,6 \% \\
1,8 \%\end{array}$ & $\begin{array}{r}100,0 \% \\
39,0 \% \\
\end{array}$ & \multirow{5}{*}{0,009} \\
\hline & Her gün & $\begin{array}{l}\text { Piyasaları Takip Sıklığı\% } \\
\text { Toplam \% }\end{array}$ & $\begin{array}{r}21,3 \% \\
3,3 \%\end{array}$ & $\begin{array}{r}42,6 \% \\
6,7 \%\end{array}$ & $\begin{array}{r}26,2 \% \\
4,1 \%\end{array}$ & $\begin{array}{l}6,6 \% \\
1,0 \%\end{array}$ & $\begin{array}{l}3,3 \% \\
0,5 \%\end{array}$ & $\begin{array}{r}100,0 \% \\
15,6 \%\end{array}$ & \\
\hline & Haftalık & $\begin{array}{l}\text { Piyasaları Takip S1klığı\% } \\
\text { Toplam \% }\end{array}$ & $\begin{array}{r}17,1 \% \\
3,1 \%\end{array}$ & $\begin{array}{r}50,0 \% \\
9,0 \%\end{array}$ & $\begin{array}{r}25,7 \% \\
4,6 \%\end{array}$ & $\begin{array}{l}4,3 \% \\
0,8 \%\end{array}$ & $\begin{array}{l}2,9 \% \\
0,5 \%\end{array}$ & $\begin{array}{r}100,0 \% \\
17,9 \%\end{array}$ & \\
\hline & Aylik & $\begin{array}{l}\text { Piyasaları Takip Sıklı̆̆ı\% } \\
\text { Toplam \% }\end{array}$ & $\begin{array}{r}15,4 \% \\
3,1 \%\end{array}$ & $\begin{array}{r}46,2 \% \\
9,2 \%\end{array}$ & $\begin{array}{r}28,2 \% \\
5,6 \%\end{array}$ & $\begin{array}{l}7,7 \% \\
1,5 \%\end{array}$ & $\begin{array}{l}2,6 \% \\
0,5 \%\end{array}$ & $\begin{array}{r}100,0 \% \\
20,0 \%\end{array}$ & \\
\hline & Yillık & $\begin{array}{l}\text { Piyasaları Takip Sıklı̆̆ı\% } \\
\text { Toplam \% }\end{array}$ & $\begin{array}{r}37,9 \% \\
2,8 \%\end{array}$ & $\begin{array}{r}34,5 \% \\
2,6 \%\end{array}$ & $\begin{array}{r}24,1 \% \\
1,8 \%\end{array}$ & $\begin{array}{l}3,4 \% \\
0,3 \%\end{array}$ & $\begin{array}{r}0 \\
0,0 \%\end{array}$ & $\begin{array}{r}100,0 \% \\
7,4 \%\end{array}$ & \\
\hline \multirow{3}{*}{ 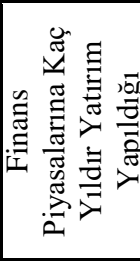 } & $0-1$ & $\begin{array}{l}\text { Yatırım Süresi \% } \\
\text { Toplam \% }\end{array}$ & $\begin{array}{r}11,7 \% \\
3,6 \%\end{array}$ & $\begin{array}{r}23,3 \% \\
7,2 \% \\
\end{array}$ & $\begin{array}{l}45,0 \% \\
13,8 \%\end{array}$ & $\begin{array}{r}11,7 \% \\
3,6 \%\end{array}$ & $\begin{array}{l}8,3 \% \\
2,6 \%\end{array}$ & $\begin{array}{r}100,0 \% \\
30,8 \%\end{array}$ & \multirow{3}{*}{0,000} \\
\hline & $2-5$ & $\begin{array}{l}\text { Yatırım Süresi \% } \\
\text { Toplam \% }\end{array}$ & $\begin{array}{r}20,5 \% \\
8,5 \%\end{array}$ & $\begin{array}{l}42,2 \% \\
17,4 \%\end{array}$ & $\begin{array}{l}27,3 \% \\
11,3 \%\end{array}$ & & $\begin{array}{l}1,2 \% \\
0,5 \%\end{array}$ & $\begin{array}{r}100,0 \% \\
41,3 \%\end{array}$ & \\
\hline & $6-10$ & $\begin{array}{l}\text { Yatırım Süresi \% } \\
\text { Toplam \% }\end{array}$ & $\begin{array}{r}21,1 \% \\
5,9 \% \\
\end{array}$ & $\begin{array}{l}46,8 \% \\
13,1 \%\end{array}$ & $\begin{array}{r}27,5 \% \\
7,7 \%\end{array}$ & $\begin{array}{l}3,7 \% \\
1,0 \%\end{array}$ & $\begin{array}{l}0,9 \% \\
0,3 \%\end{array}$ & $\begin{array}{r}100,0 \% \\
27,9 \%\end{array}$ & \\
\hline \multirow{4}{*}{ 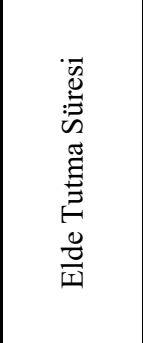 } & 1 Ay & $\begin{array}{l}\text { Elde Tutma Süresi \% } \\
\text { Toplam \% }\end{array}$ & $\begin{array}{r}15,2 \% \\
1,8 \%\end{array}$ & $\begin{array}{r}28,3 \% \\
3,3 \%\end{array}$ & $\begin{array}{r}41,3 \% \\
4,9 \%\end{array}$ & $\begin{array}{r}10,9 \% \\
1,3 \%\end{array}$ & $\begin{array}{l}4,3 \% \\
0,5 \%\end{array}$ & $\begin{array}{r}100,0 \% \\
11,8 \%\end{array}$ & \multirow{4}{*}{0,198} \\
\hline & 1 Y1l & $\begin{array}{l}\text { Elde Tutma Süresi \% } \\
\text { Toplam \% }\end{array}$ & $\begin{array}{r}10,9 \% \\
2,8 \%\end{array}$ & $\begin{array}{r}36,6 \% \\
9,5 \%\end{array}$ & $\begin{array}{r}37,6 \% \\
9,7 \%\end{array}$ & $\begin{array}{r}11,9 \% \\
3,1 \%\end{array}$ & $\begin{array}{l}3,0 \% \\
0,8 \%\end{array}$ & $\begin{array}{r}100,0 \% \\
25,9 \%\end{array}$ & \\
\hline & 2-5 Y11 & $\begin{array}{l}\text { Elde Tutma Süresi \% } \\
\text { Toplam \% }\end{array}$ & $\begin{array}{l}24,2 \% \\
11,0 \% \\
\end{array}$ & $\begin{array}{l}38,2 \% \\
17,4 \%\end{array}$ & $\begin{array}{l}28,7 \% \\
13,1 \%\end{array}$ & $\begin{array}{l}5,6 \% \\
2,6 \%\end{array}$ & $\begin{array}{l}3,4 \% \\
1,5 \%\end{array}$ & $\begin{array}{r}100,0 \% \\
45,6 \%\end{array}$ & \\
\hline & 6 ve üzeri & $\begin{array}{l}\text { Elde Tutma Süresi \% } \\
\text { Toplam \% }\end{array}$ & $\begin{array}{r}13,8 \% \\
2,3 \%\end{array}$ & $\begin{array}{r}44,6 \% \\
7,4 \%\end{array}$ & $\begin{array}{r}30,8 \% \\
5,1 \%\end{array}$ & $\begin{array}{l}7,7 \% \\
1,3 \%\end{array}$ & $\begin{array}{l}3,1 \% \\
0,5 \%\end{array}$ & $\begin{array}{r}100,0 \% \\
16,7 \%\end{array}$ & \\
\hline
\end{tabular}

Yatırımcıların finansal özellikleri ile temsil etme eğilimi arasındaki anlamlılık düzeyini belirlemek üzere oluşturulan Tablo 5'te, temsil etme ile aylık gelir arasındaki ilişkinin negatif yönlü olduğu görülmektedir. Anlamlılık değerinin 0,05 'ten büyük olması $(0,356)$ ile hipotez reddedilir. Yatırımcıların finans piyasalarındaki gelişmeleri takip sıklığı ile temsil etme eğilimi arasındaki iliş̧kiye bakıldığında, iki değişken arasında anlamlı bir ilişkinin olduğu görülmektedir. Piyasalardaki gelişmeleri izlemeyenlerin $\% 40,8$ 'i, her gün izleyenlerin \%63,9'u, haftalık izleyenlerin \%67,1'i, aylık izleyenlerin \%61,6's1, yıllık izleyenlerin de \%72,4'ü temsil etme eğilimi göstermektedirler. Temsil etme eğilimi ve finansal yatırım araçlarına kaç yıldır yatırım yapıldığ 1 gruplamasına bakıldığında pozitif yönlü bir ilişkinin olduğu görülmektedir. $\mathrm{Bu}$ durumda hipotez kabul edilir. Tabloya göre; $0-1$ yıl yatırım yapanların $\% 35$ 'i, 25 yıl yatırım yapanların $\% 62,7^{\prime}$ 'si, 6-10 y1l yatırım yapanların ise $\% 67,9$ ' u temsil etme eğilimi göstermektedirler. Temsil etme eğilimi ile yatırımcıların portföylerinde yer alan herhangi bir finansal ürünü ortalama elde tutma süreleri 
değerlendirildiğinde iki değişken arasında anlamlı bir ilişkinin olmadığı görülmektedir. Anlamlılık değerinin 0,05 'ten büyük olması $(0,198)$ hipotezin reddedildiği anlamına gelmektedir.

\section{Pişmanlıktan Kaçınma Eğilimi Hipotezleri}

1. Yatırımcıların aylık gelirleriyle pişmanlıktan kaçınma eğilimi arasında anlamlı bir ilişki vardır.

2. Yatırımcıların finans piyasalarındaki gelişmeleri izleme sıklığı ile pişmanlıktan kaçınma eğilimi arasında anlamlı bir ilişki vardır.

3. Yatırımcıların finansal yatırım araçlarına kaç yıldır yatırım yaptıkları ile pişmanlıktan kaçınma eğilimi arasında anlamlı bir ilişki vardır.

4. Yatırımcıların finansal araçları elde tutma süreleri ile pişmanlıktan kaçınma eğilimi arasında anlamlı bir ilişki vardır.

Tablo 6: Pişmanlıktan Kaçınma Eğiliminin Analizi

\begin{tabular}{|c|c|c|c|c|c|c|c|c|c|}
\hline & & & \multicolumn{5}{|c|}{ Pişmanlıktan Kaçınma Eğilimi } & \multirow[b]{2}{*}{$\begin{array}{c}\text { Topla } \\
\text { m }\end{array}$} & \multirow[b]{2}{*}{$\begin{array}{c}\text { Sig. } \\
(2-\text {-sided })\end{array}$} \\
\hline & & & 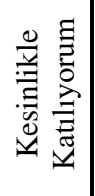 & 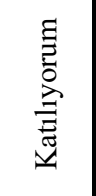 & 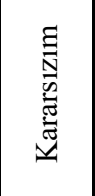 & 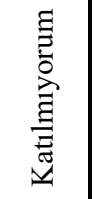 & 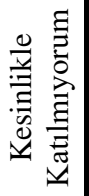 & & \\
\hline \multirow{4}{*}{ 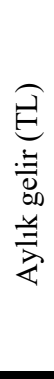 } & $1-1001$ & $\begin{array}{l}\text { Aylık gelir İçindeki \% } \\
\text { Toplam \% }\end{array}$ & $\begin{array}{r}24,1 \% \\
3,6 \% \\
\end{array}$ & $\begin{array}{r}46,6 \% \\
6,9 \% \\
\end{array}$ & $\begin{array}{r}15,5 \% \\
2,3 \% \\
\end{array}$ & $\begin{array}{r}13,8 \% \\
2,1 \% \\
\end{array}$ & $\begin{array}{r}0 \\
0,0 \% \\
\end{array}$ & $\begin{array}{r}100,0 \% \\
14,9 \% \\
\end{array}$ & \multirow{4}{*}{0,182} \\
\hline & $1001-2000$ & $\begin{array}{l}\text { Aylık gelir İçindeki \% } \\
\text { Toplam \% }\end{array}$ & $\begin{array}{r}13,6 \% \\
2,3 \%\end{array}$ & $\begin{array}{r}43,9 \% \\
7,4 \%\end{array}$ & $\begin{array}{r}25,8 \% \\
4,4 \%\end{array}$ & $\begin{array}{r}12,1 \% \\
2,1 \%\end{array}$ & $\begin{array}{l}4,5 \% \\
0,8 \%\end{array}$ & $\begin{array}{r}100,0 \% \\
16,9 \%\end{array}$ & \\
\hline & $2001-4000$ & $\begin{array}{l}\text { Aylık gelir İçindeki \% } \\
\text { Toplam \% }\end{array}$ & $\begin{array}{r}15,3 \% \\
7,9 \% \\
\end{array}$ & $\begin{array}{l}46,0 \% \\
23,8 \% \\
\end{array}$ & $\begin{array}{l}28,2 \% \\
14,6 \% \\
\end{array}$ & $\begin{array}{l}8,9 \% \\
4,6 \% \\
\end{array}$ & $\begin{array}{l}1,5 \% \\
0,8 \% \\
\end{array}$ & $\begin{array}{r}100,0 \% \\
51,8 \% \\
\end{array}$ & \\
\hline & 4001-6000 & $\begin{array}{l}\text { Aylık gelir İçindeki \% } \\
\text { Toplam İçindeki \% }\end{array}$ & $\begin{array}{r}23,4 \% \\
3,8 \%\end{array}$ & $\begin{array}{r}53,1 \% \\
8,7 \%\end{array}$ & $\begin{array}{r}17,2 \% \\
2,8 \%\end{array}$ & $\begin{array}{l}4,7 \% \\
0,8 \%\end{array}$ & $\begin{array}{l}1,6 \% \\
0,3 \%\end{array}$ & $\begin{array}{r}100,0 \% \\
16,4 \%\end{array}$ & \\
\hline \multirow{5}{*}{ 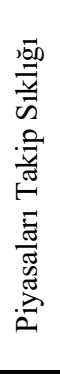 } & İzlemiyorum & $\begin{array}{l}\text { Piyasaları Takip sıklı̆̆ } 1 \% \\
\text { Toplam \% }\end{array}$ & $\begin{array}{r}12,5 \% \\
4,9 \% \\
\end{array}$ & $\begin{array}{l}36,8 \% \\
14,4 \% \\
\end{array}$ & $\begin{array}{l}32,2 \% \\
12,6 \% \\
\end{array}$ & $\begin{array}{r}16,4 \% \\
6,4 \% \\
\end{array}$ & $\begin{array}{l}2,0 \% \\
0,8 \% \\
\end{array}$ & $\begin{array}{r}100,0 \% \\
39,0 \% \\
\end{array}$ & \multirow{5}{*}{0,000} \\
\hline & Her gün & $\begin{array}{l}\text { Piyasaları Takip sıklı̆̆ } 1 \% \\
\text { Toplam \% }\end{array}$ & $\begin{array}{r}18,0 \% \\
2,8 \% \\
\end{array}$ & $\begin{array}{r}54,1 \% \\
8,5 \% \\
\end{array}$ & $\begin{array}{r}24,6 \% \\
3,8 \% \\
\end{array}$ & $\begin{array}{l}1,6 \% \\
0,3 \% \\
\end{array}$ & $\begin{array}{l}1,6 \% \\
0,3 \%\end{array}$ & $\begin{array}{r}100,0 \% \\
15,6 \% \\
\end{array}$ & \\
\hline & Aylık & $\begin{array}{l}\text { Piyasaları Takip sıklı̆̆ } 1 \% \\
\text { Toplam } \%\end{array}$ & $\begin{array}{r}17,9 \% \\
3,6 \% \\
\end{array}$ & $\begin{array}{r}48,7 \% \\
9,7 \% \\
\end{array}$ & $\begin{array}{r}21,8 \% \\
4,4 \% \\
\end{array}$ & $\begin{array}{l}9,0 \% \\
1,8 \% \\
\end{array}$ & $\begin{array}{l}2,6 \% \\
0,5 \% \\
\end{array}$ & $\begin{array}{r}100,0 \% \\
20,0 \% \\
\end{array}$ & \\
\hline & \multirow{2}{*}{ Yillik } & Piyasaları Takip sıklığı\% & $25,3 \%$ & $56,6 \%$ & $13,1 \%$ & $4,0 \%$ & $1,0 \%$ & $100,0 \%$ & \\
\hline & & Toplam \% & $6,4 \%$ & $14,4 \%$ & $3,3 \%$ & $1,0 \%$ & $0,3 \%$ & $25,4 \%$ & \\
\hline
\end{tabular}


KAÜIiBFD 9(18), 2018: 391-420

\begin{tabular}{|c|c|c|c|c|c|c|c|c|c|}
\hline \multirow{3}{*}{ 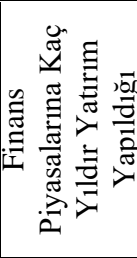 } & $0-1$ & $\begin{array}{l}\text { Yatırım Süresi \% } \\
\text { Toplam \% }\end{array}$ & $\begin{array}{l}6,7 \% \\
2,1 \% \\
\end{array}$ & $\begin{array}{r}29,2 \% \\
9,0 \% \\
\end{array}$ & $\begin{array}{l}39,2 \% \\
12,1 \% \\
\end{array}$ & $\begin{array}{r}18,3 \% \\
5,6 \% \\
\end{array}$ & $\begin{array}{l}6,7 \% \\
2,1 \% \\
\end{array}$ & $\begin{array}{r}100,0 \% \\
30,8 \% \\
\end{array}$ & \multirow{3}{*}{0,000} \\
\hline & $2-5$ & $\begin{array}{l}\text { Yatırım Süresi \% } \\
\text { Toplam \% }\end{array}$ & $\begin{array}{r}16,1 \% \\
6,7 \% \\
\end{array}$ & $\begin{array}{l}43,5 \% \\
17,9 \%\end{array}$ & $\begin{array}{l}28,6 \% \\
11,8 \%\end{array}$ & $\begin{array}{l}8,7 \% \\
3,6 \%\end{array}$ & $\begin{array}{l}3,1 \% \\
1,3 \%\end{array}$ & \begin{tabular}{|r|}
$100,0 \%$ \\
$41,3 \%$ \\
\end{tabular} & \\
\hline & $6-10$ & $\begin{array}{l}\text { Yatırım Süresi \% } \\
\text { Toplam \% }\end{array}$ & $\begin{array}{r}20,3 \% \\
3,8 \%\end{array}$ & $\begin{array}{l}60,8 \% \\
11,5 \%\end{array}$ & $\begin{array}{r}13,5 \% \\
2,6 \%\end{array}$ & $\begin{array}{l}4,1 \% \\
0,8 \%\end{array}$ & $\begin{array}{l}1,4 \% \\
0,3 \%\end{array}$ & \begin{tabular}{|r|}
$100,0 \%$ \\
$19,0 \%$
\end{tabular} & \\
\hline \multirow{5}{*}{ 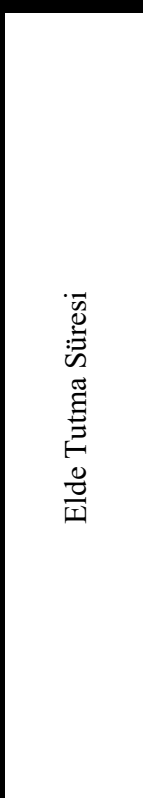 } & 1 Hafta & $\begin{array}{l}\text { Elde Tutma Süresi \% } \\
\text { Toplam \% }\end{array}$ & $\begin{array}{l}5,9 \% \\
0,8 \%\end{array}$ & $\begin{array}{r}29,4 \\
\% \\
3,8 \%\end{array}$ & $\begin{array}{r}35,3 \\
\% \\
4,6 \%\end{array}$ & $\begin{array}{r}23,5 \\
\% \\
3,1 \%\end{array}$ & $\begin{array}{l}5,9 \% \\
0,8 \%\end{array}$ & $\begin{array}{r}100,0 \\
\% \\
13,1 \\
\%\end{array}$ & \multirow{5}{*}{0,000} \\
\hline & 1 Ay & $\begin{array}{l}\text { Elde Tutma Süresi \% } \\
\text { Toplam \% }\end{array}$ & $\begin{array}{r}13,0 \\
\% \\
1,5 \%\end{array}$ & $\begin{array}{r}21,7 \\
\% \\
2,6 \%\end{array}$ & $\begin{array}{r}32,6 \\
\% \\
3,8 \%\end{array}$ & $\begin{array}{r}23,9 \\
\% \\
2,8 \%\end{array}$ & $\begin{array}{l}8,7 \% \\
1,0 \%\end{array}$ & $\begin{array}{r}100,0 \\
\% \\
11,8 \\
\%\end{array}$ & \\
\hline & $1 Y_{11}$ & $\begin{array}{l}\text { Elde Tutma Süresi \% } \\
\text { Toplam \% }\end{array}$ & $\begin{array}{r}14,9 \\
\% \\
3,8 \%\end{array}$ & $\begin{array}{r}35,6 \\
\% \\
9,2 \%\end{array}$ & $\begin{array}{r}37,6 \\
\% \\
9,7 \%\end{array}$ & $\begin{array}{l}9,9 \% \\
2,6 \%\end{array}$ & $\begin{array}{l}2,0 \% \\
0,5 \%\end{array}$ & $\begin{array}{r}100,0 \\
\% \\
25,9 \\
\%\end{array}$ & \\
\hline & 2-5 Y1l & $\begin{array}{l}\text { Elde Tutma Süresi \% } \\
\text { Toplam \% }\end{array}$ & $\begin{array}{r}18,1 \\
\% \\
5,9 \%\end{array}$ & $\begin{array}{r}59,1 \\
\% \\
19,2 \\
\%\end{array}$ & $\begin{array}{r}18,1 \\
\% \\
5,9 \%\end{array}$ & $\begin{array}{l}2,4 \% \\
0,8 \%\end{array}$ & $\begin{array}{l}2,4 \% \\
0,8 \%\end{array}$ & $\begin{array}{r}100,0 \\
\% \\
32,6 \\
\%\end{array}$ & \\
\hline & 6 ve üzeri & $\begin{array}{l}\text { Elde Tutma Süresi \% } \\
\text { Toplam \% }\end{array}$ & $\begin{array}{r}13,8 \\
\% \\
2,3 \%\end{array}$ & $\begin{array}{r}49,2 \\
\% \\
8,2 \%\end{array}$ & $\begin{array}{r}23,1 \\
\% \\
3,8 \%\end{array}$ & $\begin{array}{r}10,8 \\
\% \\
1,8 \%\end{array}$ & $\begin{array}{l}3,1 \% \\
0,5 \%\end{array}$ & $\begin{array}{r}100,0 \\
\% \\
16,7 \\
\%\end{array}$ & \\
\hline
\end{tabular}

Pişmanlıktan kaçınma eğilimi ile yatırımcıların finansal özellikleri arasındaki anlamlılık düzeyini belirlemek üzere hazırlanan Tablo 6'ya göre, aylık gelirleriyle pişmanlıktan kaçınma arasında negatif yönlü bir ilişsi olduğu görülmektedir. Anlamlılık değerinin 0,05 'ten büyük olması $(0,182)$ dolayısıyla hipotez reddedilmektedir.

Yatırımcıların piyasaları izleme sıklı̆ğ ile pişmanlıktan kaçınma eğilimi arasındaki ilişki incelendiğinde iki değişken arasında pozitif yönlü bir ilişki bulunduğu tespit edilmiş ve hipotez kabul edilmiştir. Buna göre; finans piyasalarını hiç izlemeyen katılımcıların \%49,3'ü, "her gün" izleyenlerin $\% 72,1$ 'i, “aylı" izleyenlerin \%66,6's1, “yıllık” izleyenlerin ise \%81,9'u pişmanlıktan kaçınma eğilimi sergilemektedir.

Tabloya göre pişmanlıktan kaçınma eğilimi ile yatırımcıların finans piyasalarına kaç yıldır yatırım yaptıkları arasında anlamlı bir ilişki bulunmaktadır. Bu durumda hipotez kabul edilmektedir. Finans piyasalarına " 0 1 yıl" yatırım yapanlar \%35,9 oranında, "2-5 y1l" yatırım yapanlar \%59,6 
oranında, "6-10 y1l" yatırım yapanlar \%81,1 oranında, "11-20 y11" yatırım yapanlar ise \%71,4 oranında pişmanlıktan kaçınma eğilimi göstermektedirler.

Pişmanlıktan kaçınma eğilimi ile finansal araçları elde tutma süresi değerlendirildiğine iki değişken arasında anlamlı bir ilişkiden söz edilebilmekte ve dolayısıyla hipotez kabul edilmektedir. Buna göre; finansal yatırımlarını 1 hafta elde tutanların \%35,3'ü, 1 ay elde tutanların \%33,7'si, 1 y1l elde tutanların $\% 55$ 'i, 2-5 yıl tutanların $\% 77,2$ 'si, 6 y1l ve üzeri tutanların ise $\% 63$ 'ü pişmanlıktan kaçınma eğilimi sergilemektedirler.

\section{Kayıptan Kaçınma Hipotezleri}

1. Yatırımcıların aylık gelirleriyle kayıptan kaçınma eğilimi arasında anlamlı bir ilişki vardır.

2. Yatırımcıların finans piyasalarındaki gelişmeleri izleme sıklığı ile kayıptan kaçınma eğilimi arasında anlamlı bir ilişki vardır.

3. Yatırımcıların finansal yatırım araçlarına kaç yıldır yatırım yaptıkları ile kayıptan kaçınma eğilimi arasında anlamlı bir ilişki vardır.

4. Yatırımcıların finansal araçları elde tutma süreleri ile kayıptan kaçınma eğilimi arasında anlamlı bir ilişki vardır.

Tablo 7: Kayıptan Kaçınma Eğiliminin Analizi

\begin{tabular}{|c|c|c|c|c|c|c|c|c|c|}
\hline & & & \multicolumn{5}{|c|}{ Kayıptan Kaçınma Eğilimi } & \multirow[b]{2}{*}{ Toplam } & \multirow[b]{2}{*}{$\begin{array}{c}\text { Sig. } \\
\text { (2-sided) }\end{array}$} \\
\hline & & & 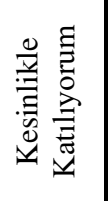 & 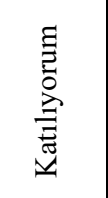 & 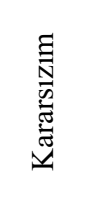 & 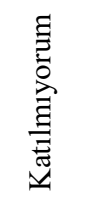 & 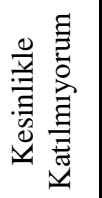 & & \\
\hline \multirow{7}{*}{ 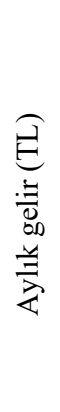 } & $1-1001$ & Aylık gelir İçindeki \% & $13,8 \%$ & $27,6 \%$ & $24,1 \%$ & $24,1 \%$ & $10,3 \%$ & $100,0 \%$ & \multirow{7}{*}{0,020} \\
\hline & \multirow{2}{*}{$1001-2000$} & Aylık gelir İçindeki \% & $19,7 \%$ & $33,3 \%$ & $27,3 \%$ & $13,6 \%$ & $6,1 \%$ & $100,0 \%$ & \\
\hline & & Toplam İçindeki \% & $3,3 \%$ & $5,6 \%$ & $4,6 \%$ & $2,3 \%$ & $1,0 \%$ & & \\
\hline & \multirow{2}{*}{$2001-4000$} & Aylık gelir İçindeki \% & $17,8 \%$ & $36,1 \%$ & $31,7 \%$ & $8,4 \%$ & $5,9 \%$ & $100,0 \%$ & \\
\hline & & Toplam İçindeki \% & $9,2 \%$ & $18,7 \%$ & $16,4 \%$ & $4,4 \%$ & $3,1 \%$ & $51,8 \%$ & \\
\hline & \multirow{2}{*}{$4001-6000$} & Aylık gelir İçindeki \% & $18,3 \%$ & $54,8 \%$ & $15,1 \%$ & $8,6 \%$ & $3,2 \%$ & $100,0 \%$ & \\
\hline & & Toplam İçindeki \% & $4,4 \%$ & $13,1 \%$ & $3,6 \%$ & $2,1 \%$ & $0,8 \%$ & $23,8 \%$ & \\
\hline
\end{tabular}


KAÜiiBFD 9(18), 2018: 391-420

\begin{tabular}{|c|c|c|c|c|c|c|c|c|c|}
\hline \multirow{8}{*}{ 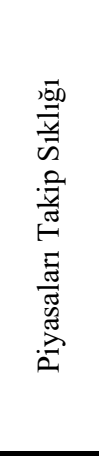 } & İzlemiyorum & $\begin{array}{l}\text { Piyasaları Takip sık.\% } \\
\text { Toplam \% }\end{array}$ & $\begin{array}{r}15,8 \% \\
6,2 \% \\
\end{array}$ & $\begin{array}{l}30,3 \% \\
11,8 \% \\
\end{array}$ & $\begin{array}{l}33,6 \% \\
13,1 \% \\
\end{array}$ & $\begin{array}{r}16,4 \% \\
6,4 \% \\
\end{array}$ & $\begin{array}{l}3,9 \% \\
1,5 \% \\
\end{array}$ & $\begin{array}{r}100,0 \% \\
39,0 \% \\
\end{array}$ & \multirow{8}{*}{0,004} \\
\hline & \multirow[t]{2}{*}{ Her gün } & Piyasaları Takip sık.\% & $23,0 \%$ & $45,9 \%$ & $14,8 \%$ & $6,6 \%$ & $9,8 \%$ & $100,0 \%$ & \\
\hline & & \begin{tabular}{|l} 
1 oplam \% \\
Pivararu Takin o/
\end{tabular} & $\begin{aligned} 3,6 \% \\
142 \%\end{aligned}$ & $\frac{1,2 \%}{420 \%}$ & $\frac{2,3 \%}{300 \%}$ & $\frac{1,0 \%}{5,7 \%}$ & $\frac{1,5 \%}{7,1 \%}$ & $\frac{15,6 \%}{1000 \%}$ & \\
\hline & Haftalık & $\begin{array}{l}\text { Pryasaları 1 akip } \\
\text { Toplam \% }\end{array}$ & $\begin{array}{r}14,3 \% \\
2,6 \%\end{array}$ & $\begin{array}{r}42,9 \% \\
7,7 \%\end{array}$ & $\begin{array}{r}30,0 \% \\
5,4 \%\end{array}$ & $\begin{array}{l}5,1 \% \\
1,0 \%\end{array}$ & $\begin{array}{l}1,1 \% \\
1,3 \%\end{array}$ & $\begin{array}{r}100,0 \% \\
17,9 \%\end{array}$ & \\
\hline & \multirow{2}{*}{ Aylik } & Piyasaları Takip sık.\% & $15,4 \%$ & $47,4 \%$ & $20,5 \%$ & $10,3 \%$ & $6,4 \%$ & $100,0 \%$ & \\
\hline & & Toplam \% & $3,1 \%$ & $9,5 \%$ & $4,1 \%$ & $2,1 \%$ & $1,3 \%$ & $20,0 \%$ & \\
\hline & \multirow{2}{*}{ Y1llik } & Piyasaları Takip sık.\% & $34,5 \%$ & $44,8 \%$ & $20,7 \%$ & 0 & 0 & $100,0 \%$ & \\
\hline & & Toplam \% & $2,6 \%$ & $3,3 \%$ & $1,5 \%$ & $0,0 \%$ & $0,0 \%$ & $7,4 \%$ & \\
\hline \multirow{8}{*}{ 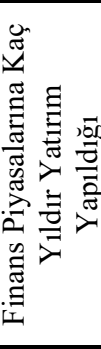 } & \multirow{2}{*}{$0-1$} & Yatırım Süresi \% & $11,7 \%$ & $25,8 \%$ & $42,5 \%$ & $13,3 \%$ & $6,7 \%$ & $100,0 \%$ & \multirow{8}{*}{0,000} \\
\hline & & Toplam \% & $3,6 \%$ & $7,9 \%$ & $13,1 \%$ & $4,1 \%$ & $2,1 \%$ & $30,8 \%$ & \\
\hline & \multirow{2}{*}{$2-5$} & Yatırım Süresi \% & $19,9 \%$ & $43,5 \%$ & $20,5 \%$ & $10,6 \%$ & $5,6 \%$ & $100,0 \%$ & \\
\hline & & Toplam \% & $8,2 \%$ & $17,9 \%$ & $8,5 \%$ & $4,4 \%$ & $2,3 \%$ & $41,3 \%$ & \\
\hline & \multirow{2}{*}{$6-10$} & Yatırım Süresi \% & $22,5 \%$ & $51,7 \%$ & $14,6 \%$ & $7,9 \%$ & $3,4 \%$ & $100,0 \%$ & \\
\hline & & Toplam \% & $5,1 \%$ & $11,8 \%$ & $3,3 \%$ & $1,8 \%$ & $0,8 \%$ & $22,8 \%$ & \\
\hline & \multirow{2}{*}{$11-20$} & Yatırım Süresi \% & $20,0 \%$ & $35,0 \%$ & $30,0 \%$ & $5,0 \%$ & $10,0 \%$ & $100,0 \%$ & \\
\hline & & Toplam \% & $1,0 \%$ & $1,8 \%$ & $1,5 \%$ & $0,3 \%$ & $0,5 \%$ & $5,1 \%$ & \\
\hline \multirow{10}{*}{ 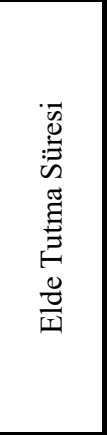 } & \multirow{2}{*}{1 Hafta } & Elde Tutma Süresi \% & $17,6 \%$ & $21,6 \%$ & $45,1 \%$ & $11,8 \%$ & $3,9 \%$ & $100,0 \%$ & \multirow{10}{*}{0,000} \\
\hline & & Toplam \% & $2,3 \%$ & $2,8 \%$ & $5,9 \%$ & $1,5 \%$ & $0,5 \%$ & $13,1 \%$ & \\
\hline & \multirow{2}{*}{1 Ay } & Elde Tutma Süresi \% & $10,9 \%$ & $26,1 \%$ & $34,8 \%$ & $17,4 \%$ & $10,9 \%$ & $100,0 \%$ & \\
\hline & & Toplam \% & $1,3 \%$ & $3,1 \%$ & $4,1 \%$ & $2,1 \%$ & $1,3 \%$ & $11,8 \%$ & \\
\hline & \multirow{2}{*}{$1 \mathrm{Y} 1 \mathrm{l}$} & Elde Tutma Süresi \% & $11,9 \%$ & $40,6 \%$ & $22,8 \%$ & $14,9 \%$ & $9,9 \%$ & $100,0 \%$ & \\
\hline & & Toplam \% & $3,1 \%$ & $10,5 \%$ & $5,9 \%$ & $3,8 \%$ & $2,6 \%$ & $25,9 \%$ & \\
\hline & \multirow{2}{*}{$2-5$ Yil } & Elde Tutma Süresi \% & $22,8 \%$ & $50,4 \%$ & $20,5 \%$ & $3,9 \%$ & $2,4 \%$ & $100,0 \%$ & \\
\hline & & Toplam \% & $7,4 \%$ & $16,4 \%$ & $6,7 \%$ & $1,3 \%$ & $0,8 \%$ & $32,6 \%$ & \\
\hline & \multirow{2}{*}{6 ve üzeri } & Elde Tutma Süresi \% & $23,1 \%$ & $40,0 \%$ & $23,1 \%$ & $10,8 \%$ & $3,1 \%$ & $100,0 \%$ & \\
\hline & & Toplam \% & $3,8 \%$ & $6,7 \%$ & $3,8 \%$ & $1,8 \%$ & $0,5 \%$ & $16,7 \%$ & \\
\hline
\end{tabular}

Tabloya 7, yatırımcıların aylık gelirleri ile kayıptan kaçınma eğilimi arasında anlamlı bir ilişki olduğunu göstermektedir. Pearson anlamlılık değerinin 0,020 çıkması hipotezin kabul edildiği anlamına gelmektedir. Analiz sonucuna göre; aylık gelirleri 1-1000 TL arasında olan yatırımcıların \%41,4'ü, 1001-2000 TL olanların \%54'ü, 2001-4000 TL olanların \%53,9'u, 4000-6000 TL arası olanların ise \% 73, 1'i kayıptan kaçınma eğilimi göstermektedirler.

Yatırımcıların piyasaları takip sıklığı ile kayıptan kaçınma eğilimi arasındaki ilişkiye bakıldığında iki değişken arasında pozitif yönlü bir ilişkinin olduğu görülmektedir. P değerinin 0,05 'ten küçük olması $(0,004)$ hipotez kabul edilmektedir. Kayıptan kaçınma eğilimi içerisinde olanların \%64,2'si finans piyasalarını hiç takip etmezken, $\% 38,2$ 'si her gün, $\% 33,8$ 'i haftalık, $\% 62,8$ 'i ise yıllık olarak piyasalardaki gelişmeleri izlemektedirler. 
Yatırımcıların kaç yıldır finansal araçlara yatırım yaptığı ile kayıptan kaçınma eğilimi gruplamasında bakıldığında aralarında anlamlı bir ilişkiden söz edilebilmektedir. Ki-kare analiz sonucuna göre iki değişken arasında anlamlı bir ilişkiden söz edilebilmektedir. Oluşan $\mathrm{P}$ değeri $(0,000)$ ile hipotez kabul edilmektedir. $\mathrm{Bu}$ durumda; finans piyasalarına $0-1$ yıl yatırım yapanlar \%37,5 oranında, 2-5 yıl yatırım yapanlar \%63,4 oranında, 6-10 yıl yapanlar \%74,2 oranında, 11-20 yıl arasında yatırım yapanlar ise \%55 oranında kayıtan kaçınma eğilimi göstermektedirler. Yatırımcıların finansal ürünleri elde tutma sürelerine bakıldığında ise iki değişken arasında anlamlı bir ilişkinin olduğu görülmektedir. Bu durumda hipotez kabul edilmektedir.

Tabloya göre sahip oldukları finansal araçları 1 hafta ellerinde tutan yatırımciların \%39,2'si, 1 ay tutanların \%37'si, 1 y1l tutanların \%52,5'i, 2-5 y1l arası tutanların \%73,2'si, 6 yıl ve üzeri tutanların ise $\% 63,1$ 'i kayıptan kaçınma eğilimi göstermektedir.

\section{Aşina Olanı Tercih Etme Hipotezleri}

1. Yatırımcıların aylık gelirleriyle aşina olanı tercih etme eğilimi arasında anlamlı bir ilişki vardır.

2. Yatırımcıların finans piyasalarındaki gelişmeleri izleme sıklığı ile aşina olanı tercih etme arasında anlamlı bir ilişki vardır.

3. Yatırımcıların finansal yatırım araçlarına kaç yıldır yatırım yaptıkları ile aşina olanı tercih etme eğilimi arasında anlamlı bir ilişki vardır.

4. Yatırımcıların finansal araçları elde tutma süreleri ile aşina olanı tercih etme eğilimi arasında anlamlı bir ilişki vardır.

Tablo 8: Așina Olanı Tercih Etme Eğiliminin Analizi

\begin{tabular}{|c|c|c|c|c|c|c|c|c|c|}
\hline & & & \multicolumn{5}{|c|}{ Aşina Olanı Tercih Etme Eğilimi } & \multirow[b]{2}{*}{ Toplam } & \multirow[b]{2}{*}{$\begin{array}{c}\text { Sig. } \\
(2-\text { sided })\end{array}$} \\
\hline & & & 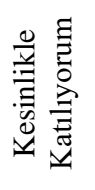 & 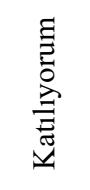 & 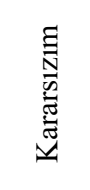 & 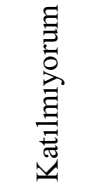 & 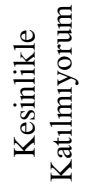 & & \\
\hline \multirow{5}{*}{ 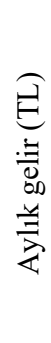 } & $1-1001$ & $\begin{array}{l}\text { Aylık gelir İçindeki \% } \\
\text { Toplam İçindeki \% }\end{array}$ & $\begin{array}{r}17,2 \% \\
1,3 \%\end{array}$ & $\begin{array}{r}24,1 \% \\
1,8 \%\end{array}$ & $\begin{array}{r}37,9 \% \\
2,8 \%\end{array}$ & $\begin{array}{r}13,8 \% \\
1,0 \%\end{array}$ & $\begin{array}{l}6,9 \% \\
0,5 \%\end{array}$ & $\begin{array}{r}100,0 \% \\
7,4 \%\end{array}$ & \multirow{5}{*}{0,030} \\
\hline & $1001-2000$ & $\begin{array}{l}\text { Aylık gelir İçindeki \% } \\
\text { Toplam İçindeki \% }\end{array}$ & $\begin{array}{r}15,2 \% \\
2,6 \%\end{array}$ & $\begin{array}{r}36,4 \% \\
6,2 \%\end{array}$ & $\begin{array}{r}21,2 \% \\
3,6 \%\end{array}$ & $\begin{array}{r}15,2 \% \\
2,6 \%\end{array}$ & $\begin{array}{r}12,1 \% \\
2,1 \%\end{array}$ & $\begin{array}{r}100,0 \% \\
16,9 \%\end{array}$ & \\
\hline & $2001-4000$ & $\begin{array}{l}\text { Aylık gelir İçindeki \% } \\
\text { Toplam İçindeki \% }\end{array}$ & $\begin{array}{r}13,9 \% \\
7,2 \% \\
\end{array}$ & $\begin{array}{l}33,7 \% \\
17,4 \%\end{array}$ & $\begin{array}{l}23,3 \% \\
12,1 \%\end{array}$ & $\begin{array}{r}15,8 \% \\
8,2 \%\end{array}$ & $\begin{array}{r}13,4 \% \\
6,9 \%\end{array}$ & $\begin{array}{r}100,0 \% \\
51,8 \%\end{array}$ & \\
\hline & \multirow{2}{*}{$4001-6000$} & Aylık gelir İçindeki \% & $9,7 \%$ & $55,9 \%$ & $10,8 \%$ & $10,8 \%$ & $12,9 \%$ & $100,0 \%$ & \\
\hline & & Toplam İçindeki \% & $2,3 \%$ & $13,3 \%$ & $2,6 \%$ & $2,6 \%$ & $3,1 \%$ & $23,8 \%$ & \\
\hline
\end{tabular}


Tablo 8 (Devam): Așina Olanı Tercih Etme Eğiliminin Analizi

\begin{tabular}{|c|c|c|c|c|c|c|c|c|c|}
\hline \multirow{5}{*}{ 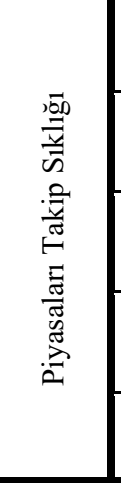 } & İzlemiyorum & $\begin{array}{l}\text { Piyasaları Takip sık.\% } \\
\text { Toplam \% }\end{array}$ & $\begin{array}{r}11,2 \% \\
4,4 \% \\
\end{array}$ & $\begin{array}{l}25,7 \% \\
10,0 \% \\
\end{array}$ & $\begin{array}{l}28,3 \% \\
11,0 \% \\
\end{array}$ & $\begin{array}{r}19,1 \% \\
7,4 \% \\
\end{array}$ & $\begin{array}{r}15,8 \% \\
6,2 \% \\
\end{array}$ & $\begin{array}{r}100,0 \% \\
39,0 \% \\
\end{array}$ & \multirow{5}{*}{0,000} \\
\hline & Her gün & $\begin{array}{l}\text { Piyasaları Takip sık.\% } \\
\text { Toplam \% }\end{array}$ & $\begin{array}{r}14,8 \% \\
2,3 \% \\
\end{array}$ & $\begin{array}{r}39,3 \% \\
6,2 \% \\
\end{array}$ & $\begin{array}{r}13,1 \% \\
2,1 \% \\
\end{array}$ & $\begin{array}{r}13,1 \% \\
2,1 \% \\
\end{array}$ & $\begin{array}{r}19,7 \% \\
3,1 \% \\
\end{array}$ & $\begin{array}{r}100,0 \% \\
15,6 \% \\
\end{array}$ & \\
\hline & Haftalık & $\begin{array}{l}\text { Piyasaları Takip sık.\% } \\
\text { Toplam \% }\end{array}$ & $\begin{array}{r}18,6 \% \\
3,3 \%\end{array}$ & $\begin{array}{r}48,6 \% \\
8,7 \%\end{array}$ & $\begin{array}{r}18,6 \% \\
3,3 \%\end{array}$ & $\begin{array}{l}7,1 \% \\
1,3 \%\end{array}$ & $\begin{array}{l}7,1 \% \\
1,3 \%\end{array}$ & $\begin{array}{r}100,0 \% \\
17,9 \%\end{array}$ & \\
\hline & Aylık & $\begin{array}{l}\text { Piyasaları Takip s1k.\% } \\
\text { Toplam \% }\end{array}$ & $\begin{array}{l}9,0 \% \\
1,8 \% \\
\end{array}$ & $\begin{array}{r}46,2 \% \\
9,2 \% \\
\end{array}$ & $\begin{array}{r}20,5 \% \\
4,1 \% \\
\end{array}$ & $\begin{array}{r}16,7 \% \\
3,3 \% \\
\end{array}$ & $\begin{array}{l}7,7 \% \\
1,5 \% \\
\end{array}$ & $\begin{array}{r}100,0 \% \\
20,0 \% \\
\end{array}$ & \\
\hline & Yillik & $\begin{array}{l}\text { Piyasaları Takip sık.\% } \\
\text { Toplam \% }\end{array}$ & $\begin{array}{r}20,7 \% \\
1,5 \% \\
\end{array}$ & $\begin{array}{r}62,1 \% \\
4,6 \%\end{array}$ & $\begin{array}{l}6,9 \% \\
0,5 \%\end{array}$ & $\begin{array}{l}3,4 \% \\
0,3 \%\end{array}$ & $\begin{array}{l}6,9 \% \\
0,5 \%\end{array}$ & $\begin{array}{r}100,0 \% \\
7,4 \%\end{array}$ & \\
\hline \multirow{4}{*}{ 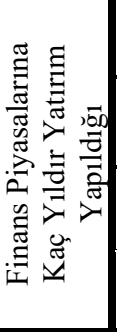 } & $0-1$ & $\begin{array}{l}\text { Yatırım Süresi \% } \\
\text { Toplam \% } \\
\end{array}$ & $\begin{array}{l}5,8 \% \\
1,8 \% \\
\end{array}$ & $\begin{array}{r}21,7 \% \\
6,7 \% \\
\end{array}$ & $\begin{array}{l}38,3 \% \\
11,8 \% \\
\end{array}$ & $\begin{array}{r}19,2 \% \\
5,9 \% \\
\end{array}$ & $\begin{array}{r}15,0 \% \\
4,6 \% \\
\end{array}$ & $\begin{array}{r}100,0 \% \\
30,8 \% \\
\end{array}$ & \multirow{4}{*}{0,000} \\
\hline & $2-5$ & $\begin{array}{l}\text { Yatırım Süresi \% } \\
\text { Toplam \% }\end{array}$ & $\begin{array}{r}15,5 \% \\
6,4 \%\end{array}$ & $\begin{array}{l}41,6 \% \\
17,2 \%\end{array}$ & $\begin{array}{r}15,5 \% \\
6,4 \%\end{array}$ & $\begin{array}{r}12,4 \% \\
5,1 \%\end{array}$ & $\begin{array}{r}14,9 \% \\
6,2 \%\end{array}$ & $\begin{array}{r}100,0 \% \\
41,3 \%\end{array}$ & \\
\hline & $6-10$ & $\begin{array}{l}\text { Yatırım Süresi \% } \\
\text { Toplam \% }\end{array}$ & $\begin{array}{r}21,6 \% \\
4,1 \%\end{array}$ & $\begin{array}{l}54,1 \% \\
10,3 \%\end{array}$ & $\begin{array}{l}8,1 \% \\
1,5 \%\end{array}$ & $\begin{array}{l}9,5 \% \\
1,8 \%\end{array}$ & & $\begin{array}{r}100,0 \% \\
19,0 \%\end{array}$ & \\
\hline & $11-20$ & $\begin{array}{l}\text { Yatırım Süresi \% } \\
\text { Toplam \% }\end{array}$ & $\begin{array}{r}11,4 \% \\
1,0 \% \\
\end{array}$ & $\begin{array}{r}51,4 \% \\
4,6 \%\end{array}$ & $\begin{array}{r}14,3 \% \\
1,3 \%\end{array}$ & $\begin{array}{r}17,1 \% \\
1,5 \%\end{array}$ & $\begin{array}{l}5,7 \% \\
0,5 \%\end{array}$ & $\begin{array}{r}100,0 \% \\
9,0 \%\end{array}$ & \\
\hline \multirow{5}{*}{ 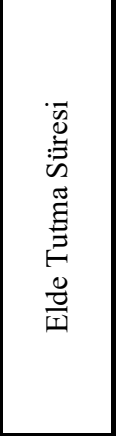 } & $1 \mathrm{Hafta}$ & $\begin{array}{l}\text { Elde Tutma Süresi \% } \\
\text { Toplam \% } \\
\end{array}$ & $\begin{array}{l}9,8 \% \\
1,3 \% \\
\end{array}$ & $\begin{array}{r}27,5 \% \\
3,6 \% \\
\end{array}$ & $\begin{array}{r}35,3 \% \\
4,6 \% \\
\end{array}$ & $\begin{array}{r}15,7 \% \\
2,1 \% \\
\end{array}$ & $\begin{array}{r}11,8 \% \\
1,5 \% \\
\end{array}$ & $\begin{array}{r}100,0 \% \\
13,1 \% \\
\end{array}$ & \multirow{5}{*}{0,000} \\
\hline & $1 \mathrm{Ay}$ & $\begin{array}{l}\text { Elde Tutma Süresi \% } \\
\text { Toplam \% }\end{array}$ & $\begin{array}{l}8,7 \% \\
1,0 \% \\
\end{array}$ & $\begin{array}{r}15,2 \% \\
1,8 \% \\
\end{array}$ & $\begin{array}{r}32,6 \% \\
3,8 \% \\
\end{array}$ & $\begin{array}{r}17,4 \% \\
2,1 \% \\
\end{array}$ & $\begin{array}{r}26,1 \% \\
3,1 \% \\
\end{array}$ & $\begin{array}{r}100,0 \% \\
11,8 \% \\
\end{array}$ & \\
\hline & $1 Y_{11}$ & $\begin{array}{l}\text { Elde Tutma Süresi \% } \\
\text { Toplam \% }\end{array}$ & $\begin{array}{l}7,9 \% \\
2,1 \% \\
\end{array}$ & $\begin{array}{r}30,7 \% \\
7,9 \% \\
\end{array}$ & $\begin{array}{r}26,7 \% \\
6,9 \% \\
\end{array}$ & $\begin{array}{r}17,8 \% \\
4,6 \% \\
\end{array}$ & $\begin{array}{r}16,8 \% \\
4,4 \% \\
\end{array}$ & $\begin{array}{r}100,0 \% \\
25,9 \% \\
\end{array}$ & \\
\hline & $2-5$ Y1l & $\begin{array}{l}\text { Elde Tutma Süresi \% } \\
\text { Toplam \% }\end{array}$ & $\begin{array}{r}20,5 \% \\
6,7 \% \\
\end{array}$ & $\begin{array}{l}54,3 \% \\
17,7 \%\end{array}$ & $\begin{array}{r}11,0 \% \\
3,6 \%\end{array}$ & $\begin{array}{l}7,1 \% \\
2,3 \%\end{array}$ & $\begin{array}{l}7,1 \% \\
2,3 \%\end{array}$ & $\begin{array}{r}100,0 \% \\
32,6 \%\end{array}$ & \\
\hline & 6 ve üzeri & $\begin{array}{l}\text { Elde Tutma Süresi \% } \\
\text { Toplam \% }\end{array}$ & $\begin{array}{r}13,8 \% \\
2,3 \%\end{array}$ & $\begin{array}{r}46,2 \% \\
7,7 \%\end{array}$ & $\begin{array}{r}12,3 \% \\
2,1 \%\end{array}$ & $\begin{array}{r}20,0 \% \\
3,3 \%\end{array}$ & $\begin{array}{l}7,7 \% \\
1,3 \%\end{array}$ & $\begin{array}{r}100,0 \% \\
16,7 \%\end{array}$ & \\
\hline
\end{tabular}

Yatırımcıların finansal özellikleri ile aşina olanı tercih etme eğilimi arasında ilişkiyi belirlemek üzere oluşturulan Tablo 8'e göre; aylık geliri 1-1000 TL arası olanların \%41,3'ü, 1001-2000 TL aras1 olanların \%51,6'sı, 2001-4000 TL aras1 olanların \%47,6's1, 4001-6000 TL aras1 olan yatırımciların ise $\% 65,7$ 'si aşina olanı tercih etme eğilimi göstermektedirler. Bu durumda hipotez kabul edilmektedir.

Tabloya göre aşina olma eğilimi ile yatırımcıların piyasaları takip sıklığı arasında anlamlı bir ilişkinin bulunduğu görülmektedir. Finans piyasalarındaki gelişmeleri hiç takip etmeyenlerin $\% 36,9$ 'u her gün takip edenlerin $\% 54,1^{\prime} \mathrm{i}$, haftalı edenlerin \%67,2'si, aylık edenlerin \%55,2'si, y1llık edenlerin ise 
\%82,8'i aşina olanı tercih etme eğilimi özellikleri taşımaktadırlar.

Finansal yatırım araçlarına kaç yıldır yatırım yapıldı̆̆ı ile aşina olanı tercih etme eğilimi arasında pozitif yönlü ilişkinin görüldüğü tabloda; finans piyasalarına $0-1$ yıl yatırım yapanlar \%27,5 oranında, 2-5 yıl yatırım yapanlar $\% 57,1$ oranında, 6-10 yıl yapanlar \%75,7 oranında, 11-20 yıl arasında yatırım yapanlar ise \%62,8 oranında aşina olanı tercih etme eğilimi göstermektedirler.

Tabloya göre yatırımları elde tutma süresi ile aşina olanı tercih etme arasında anlamlı bir ilişkinin olduğundan söz edilebilmektedir. P değerinin 0,000 çıkması ile hipotez kabul edilmektedir. Buna göre sahip oldukları finansal araçları 1 hafta ellerinde tutan yatırımcilar $\% 37,3,1$ ay tutanlar $\% 23,9,1$ y1l tutanlar \%38,6, 2-5 y1l arası tutanlar \%74,8, 6 yıl ve üzeri tutanlar ise $\% 60$ oranında aşina olanı tercih etme eğilimi göstermektedir.

\section{SONUÇ}

Anket katılımcılarının finansal özellikleri ve davranışsal eğilimlerinin analizi sonucunda aşırı iyimserlik eğilimi ile yatırımcıların aylık gelir durumları arasında anlamlı bir ilişkinin bulunmadığı tespit edilmiştir. Aşırı iyimserlik eğilimi finans piyasalarındaki gelişmeleri izleme sıklığı arasındaki ilişki ölçümlenmiş ve aralarında anlamlı bir ilişkinin bulunduğu anlaşılmıştır. Aşırı iyimserlik eğilimi ile yatırımcıların finansal yatırım araçlarına kaç yıldır yatırım yaptıkları ve finansal araçları elde tutma sürelerinin ayrı ayrı değerlendirilmesi sonucu her ikisiyle de anlamlı sonuçlar bulunduğu görülmüştür.

Mevcudiyet eğilimi ile yatırımcıların aylık gelir durumları arasındaki ilişki değerlendirildiğinde aralarında anlamlı bir ilişki bulunmaktadır. Mevcudiyet eğilimi ile yatırımcıların finans piyasalarındaki gelişmeleri izleme sıklığı arasında da anlamlı bir ilişki tespit edilmiştir. Mevcudiyet eğilimi ile yatırımcıların finansal yatırım araçlarına kaç yıldır yatırım yaptıkları ve finansal araçları elde tutma sürelerinin ayrı ayrı analiz edilmesiyle her ikisiyle de anlamlı sonuçlar elde edilmiştir.

Temsil etme eğilimi ile yatırımcıların aylık gelir durumları arasındaki ilişkiye bakıldığında değişkenler arası anlamlı bir ilişkinin bulunmadığı, diğer taraftan temsil etme eğilimi ile finans piyasalarındaki gelişmeleri izleme sıklığı arasındaki ilişki ölçümlenmiş ve aralarında anlamlı bir ilişkinin olduğu anlaşılmıştır. Temsil etme eğilimi, yatırımcıların finansal yatırım araçlarına kaç yıldır yatırım yaptıkları ve finansal araçları elde tutma süreleri ile çapraz analiz edilmiş, sonuç olarak kaç yıldır yatırım yaptıkları ile aralarında anlamlı bir

\section{6}


ilişkinin olduğu görülmüş, finansal araçları elde tutma süresiyle ise aralarında anlamlı bir ilişki bulunamamıştır. Pişmanlıktan kaçınma eğiliminin finansal faktörlerle ki-kare analiz sonuçlarına göre; aylık gelir durumuyla aralarında anlamlı bir ilişki olmadığı, finans piyasalarındaki gelişmeleri izleme sıklığı, finansal yatırım araçlarına kaç yıldır yatırım yapıldığ 1 ve finansal araçları elde tutma süresiyle ise aralarında anlamlı bir ilişki olduğu ortaya konmuştur.

Kayıptan kaçınma eğilimi ile yatırımcıların aylık gelir durumları, finans piyasalarını izleme sıklığı, yatırım araçlarına kaç yıldır yatırım yapıldığı ve finansal araçları elde tutma süresi aralarında anlamlı bir ilişkinin olduğu görülmüştür.

Aşina olanı tercih etme davranışı ile yatırımcıların aylık gelir durumları arasındaki ilişki değerlendirildiğinde aralarında anlamlı bir ilişki bulunmadığı tespit edilmiştir. Aşina olanı tercih etme eğilimi ile finans piyasalarındaki gelişmeleri izleme sıklığı arasındaki ilişki ölçümlenmiş ve aralarında anlamlı bir ilişkinin olduğu bulunmuştur. Aşina olanı tercih etme eğiliminin, finansal yatırım araçlarına kaç yıldır yatırım yapıldığı ve finansal araçları elde tutma süreleri ile de aralarında anlamlı bir ilişki olduğu tespit edilmiştir.

$\mathrm{Bu}$ çalışmada, yatırımcıların finansal özellikleri ile davranışsal finansın ana teması olan psikolojik eğilimleri çapraz analiz edilmiştir. Sonuç olarak, Erzincan ilindeki yatırımcıların karar verme sürecinde her zaman rasyonel davranışlar sergilemedikleri, zaman zaman psikolojik ve sosyolojik etkenlerle irrasyonel davranışlarda sergiledikleri ortaya konmuştur. Böylece geleneksel finans teorilerinin temel varsayımı olan rasyonelliğin her zaman geçerli olmadığı söylenebilir.

\section{KAYNAKLAR}

Akman, N. (2009). Finansal açılklama üzerinde kültürün etkisi: UFRS öncesi ve sonrası Yayımlanmamış Doktora Tezi, Başkent Üniversitesi Sosyal Bilimler Enstitüsü, İşletme Bölümü Muhasebe Ve Finansman Anabilim Dalı.

Aldemir, S. (2015). Davranışsal finans açısından yatırımcı davranışlarının incelenmesi: Tokat ili örneği. Yayımlanmamış Yüksek Lisans Tezi, Gazi Osmanpaşa Üniversitesi.

Alpdündar, H. S. (2016). Bireylerin sigorta eğilimlerini yönlendiren faktörlerin davranışsal finans yaklaşımı ile incelenmesi. Yayımlanmamış Yüksek Lisans Tezi, İstanbul Ticaret Üniversitesi Finans Enstitüsü, Finans Anabilim Dalı, Uluslararası Bankacılık Ve Finans Bilim Dalı.

Alper, D. \& Ertan, Y. (2008). Yatırım fonu seçim kararlarında çerçeveleme 
etkisi. Muhasebe Ve Finansman Dergisi, 37, 174-184.

Altıngül, M. (2015). Özel alışveriş sitelerine yönelik algılanan hizmet kalitesinin bilişsel çelişki, iç tepkisel satın alma ve yeniden satın alma niyeti üzerindeki etkisi. Yayımlanmamış Yüksek Lisans Tezi, İstanbul Üniversitesi İşletme Anabilim Dalı, İstanbul

Aslan, R. (2016). Bireysel yatırımcılarl finansal yatırıma yönlendiren faktörlerin davranışsal finans açısından araştırılması: Şanlıurfa iline bağlı Viranşehir İlçesi örneği. Yayımlanmamış Yüksek Lisans Tezi, Çağ Üniversitesi Sosyal Bilimler Enstitüsü, İşletme Yönetimi Anabilim Dalı.

Ateş, A. (2007). Finansal yatırımların davranışsal finans açısından değerlendirilmesi üzerine bir araştırma. Selçuk Üniversitesi Sosyal Bilimler Enstitüsü İşletme Ana Bilim Dalı Muhasabe-Finansman Bilim Dalı.

Aytekin, Y. E. (2015). Davranışsal finans kapsamında bireysel yatırımcıların incelenmesi: Van ili örneği. Yayımlanmamış Yüksek Lisans Tezi. Yüzüncü Yıl Üniversitesi Sosyal Bilimler Enstitüsü İşletme Anabilim Dalı.

Baker, H. K. \& Nofsinger, J. R. (2002). Psychological biases of 1nvestors. Financial Services Review, 1(1), 97-116.

Barak, O. (2006). Hisse senedi piyasalarında anomaliler ve bunları açılamak üzere geliştirilen davranıssal finans modelleri IMKB'de bir uygulama. Yayımlanmamış Doktora Tezi, Gazi Üniversitesi Sosyal Bilimler Enstitüsü.

Barak, O. (2008). İMKB'de aşırı reaksiyon anomalisi ve davranışsal finans modelleri kapsamında değerlendirilmesi. Gazi Üniversitesi İktisadi Ve İdari Bilimler Fakültesi Dergisi, 10(1), 207-229.

Barberis, N. Shleifer, A. \& Vishny, R. (1998). A model of investor sentiment. Journal Of Financial Economics, 49, 307-343.

Bayar, Y. (2011). Yatırımcı davranışlarının davranışçı yaklaşım çerçevesinde değerlendirilmesi. Girişimcilik ve Kalkınma Dergisi, 6(2), 133-160.

Böyükaslan, A. (2012). Bireysel yatırımcıları finansal yatırım kararına yönlendiren faktörlerin davranışsal finans açısından incelenmesi: Afyonkarahisar örneği. Yayımlanmamış Y. Lisans Tezi, Afyonkarahisar Üniversitesi Sosyal Bilimler Enstitüsü.

Choi, J., Kim, Y. S. \& Mitov, I. (2015). Reward-risk momentum strategies using classical tempered stable distribution. Journal Of Banking \& Finance, 58, 194213.

Çelik, T. T. \& Taş, O. (2007). Etkin piyasa hipotezi ve gelişmekte olan hisse senedi piyasalar1, $\dot{I} \ddot{U}$ Dergisi/B, 4(2), 12-22.

Çevik, E. İ. (2012). İstanbul Menkul Kıymetler Borsası'nda etkin piyasa hipotezinin uzun hafıza modelleri ile analizi: Sektörel bazda bir inceleme. Yaşar Üniversitesi Dergisi, 26(7), 4437-4454.

De Bondt, W. F. M. \& Thaler, R. (1985). Does the stock market overreact?. The Journal Of Finance, 11(3), 793-805.

Demir, Y. \& Yağcılar Göçmen, G. (2009). İMKB'de işlem gören banka hisse senetlerinin getirilerini etkileyen faktörlerin arbitraj fiyatlama modeli ile belirlenmesi. Alanya Işletme Fakültesi Dergisi, 1(2), 36-51.

Doğukanlı, H. \& Ergün, B. (2011). Davranışsal finans etkin piyasalara karşı: Aşırı tepki 
hipotezinin İKK'de araştırılması. Ç.Ü. Sosyal Bilimler Enstitüsü Dergisi, 20(1), 321-336.

Ede, M. (2007). Davranışsal finans ve bireysel yatırımcı davranışları üzerine ampirik bir uygulama. Yayımlanmamış Yüksek Lisans Tezi, Marmara Üniversitesi Bankacılık Ve Sigortacılık Enstitüsü.

Ege, İ., Topaloğlu, E. E. \& Coşkun, D. (2012). davranışsal finans ve anomaliler: Ocak ay1 anomalisinin İMKB'de test edilmesi. Muhasebe Ve Finansman Dergisi, 56, 175-190.

Gümüş, F. B., Koç, M. \& Agalarova, M. (2013). Bireysel yatırımcıların yatırım kararları üzerinde etkili olan demografik ve psikolojik faktörlerin tespiti üzerine bir çalışma uygulaması: Türkiye Ve Azerbaycan uygulaması. Kafkas Üniversitesi İktisadi ve İdari Bilimler Fakültesi Dergisi, 4(6), 1309-4289.

Güngör, M. \& Bulut, Y. (2008). Ki-kare testi üzerine. Doğu Anadolu Bölgesi Araştırmaları.

Hong, H. \& Stein, Jeremy C. (1999). A unified theory of underreaction, momentum trading, and overraction in asset markets. Journal Of Finance, 54(6), 2143-2184.

Jegadeesh, N. \& Titman, S. (2001). Profitability of momentum strategies: An evaluation of alternative explanations. Journal Of Finance, 56, 699-721.

Kahyaoğlu, M. B. (2011). Yatırım kararlarına etki eden çeşitli duygusal ve psikolojik faktörlere maruz kalma düzeyi üzerinde cinsiyetin rolü: İMKB bireysel hisse senedi yatırımcıları üzerine bir uygulama. Ekonomik Ve Sosyal Araştırmalar Dergisi, 7(1), 29-51.

Kandır, S. Y., Çerçi, G. \& Uzkaralar, Ö. (2013). Yatırımcı duyarlılığı temsilcileri: Yatırım ortaklıkları 1skontosu ve tüketici güven endeksi örneği. BDDK Bankacilık ve Finansal Piyasalar Dergisi, 7(2), 55-75.

Karan, M. B. (2006). Yatırım analizi ve portföy yönetimi, Ankara, Gazi Yayınevi.

Karan, M. B. (2013). Yatırım analizi ve portföy yönetimi, Ankara, Gazi Yayınevi.

Kılıç, S. (2016). Cronbach'ın Alfa Güvenirlik Katsayısı, Gülhane Askeri Tıp Fakültesi, Ankara,

Küçük, A. (2014). Bireysel yatırımcıları finansal yatırım kararına yönlendiren faktörlerin davranışsal finans açısından ele alınması: Osmaniye örneği. Akademik Araştırmalar ve Çalışmalar Dergisi, 6(11), 104-122.

Küden, M. (2014). Davranışsal finans açısından bireysel yatırım tercihlerinin değerlendirilmesi. Yayımlanmamış Yüksek Lisans Tezi, Gediz Üniversitesi Sosyal Bilimler Enstitüsü.

Kök, D. \& Uyğur, M. E. (2014). Finansal piyasalarda fiyat etkileşimi: BİST 100 ve seçilmiş finansal göstergeler için var analizi. Pamukkale İşletme ve Bilişim Yönetimi Dergisi, 1(1), 1-23.

Miffre, J. Ve Rallis, G. (2007). Momentum strategies in commodity futures markets. Journal Of Banking \& Finance, 31, 1863-1886.

Oran A., Y1lmaz, Ö. \& Özer, T. G. (2010). Türkiye'de algısal sapmalar. Dokuz Eylül Üniversitesi Işletme Fakültesi Dergisi, 11(2), 297-307.

Otluoğlu, E. (2009). İstanbul davranışsal finans çerçevesinde aşırı güven hipotezinin test edilmesi: IMKB'de bir uygulama. Yayımlanmamış Yüksek Lisans Tezi, İstanbul Üniversitesi Sosyal Bilimler Enstitüsü İşletme Anabilim Dalı 
Finansman Bilim Dalı, İstanbul.

Rachev, S., Jasic, T., Stoyanov, S. \& Fabozzi F. J. (2007). Momentum strategies based on reward-risk stock selection criteria, Journal Of Banking \& Finance 31, 23252346.

Sevim, Ş. \& Akkoç, S. (2007). Sermaye piyasalarında düşük fiyat etkisi ve İstanbul Menkul Kıymetler Borsası'nda bir uygulama. Eskişehir Osmangazi Üniversitesi Sosyal Bilimler Dergisi, 8(1).

Sönmez, T. (2010). Davranışsal finans yaklaşımı: IMKB'de aşırı tepki hipotezi üzerine bir araştırma. Yayımlanmamış Doktora Tezi, Hacettepe Üniversitesi Sosyal Bilimler Enstitüsü İşletme Anabilim Dalı.

Süer, Ö. (2007). Yatırım kararlarında makale alınan risk düzeyinin belirlenmesine ilişkin ampirik bir çalışma. Öneri Dergisi, 7(28), 97-105.

Sümer, K. K. \& Hepsağ, A. (2007). Finansal varlık fiyatlama modelleri çerçevesinde piyasa risklerinin hesaplanması: Parametrik olmayan yaklaşım. Bankacılar Dergisi, 62, 3-24.

Şenkesen, E. (2009). Davranışsal finans ve yatırımcı duyarlılı̆̆ının tahvil verimi üzerindeki etkisi: IMKB tahvil ve bono piyasasında bir uygulama. Yayımlanmamış Doktora Tezi, İstanbul Üniversitesi, İşletme Anabilim Dalı, İstanbul.

Taner, B. \& Akkaya, G. C. (2005). Yatırımcı psikolojisi ve davranışsal finans yaklaşım1. Muhasebe Ve Finansman Dergisi, 27, 47-54.

Tomak, S. (2011). Girişimcilik ve bilişsel yanlılık. Girişimcilik Ve Kalkınma Dergisi, 6(1), 72-95.

Tufan, E. (2006). Davranışsal finans. Ankara: Orion Yayınevi.

Tufan, C. \& Sarıçiçek, R. (2013). Davranışsal finans modelleri, etkin piyasa hipotezi ve anomalilerine ilişkin bir değerlendirme. Trakya Üniversitesi Sosyal Bilimler Dergisi, 15(2), 159-182.

Yıldız, S. B., Kalaycı, Ş., Demir, Y. \& Göksu, Ş. A. (2009). Yatırımcıların psikolojik önyargıları: İMKB üzerine ampirik bir çalışma. Finans Politik \& Ekonomik Yorumlar, 46(537), 91-106.

Yüksel, N. D. (2009). IMKB'de yatırımcı davranışı ve örnek bir uygulama. Yayımlanmamış Y. Lisans Tezi, Dokuz Eylül Üniversitesi Sosyal Bilimler Enstitüsü.

Wang, M., Keller, C. \& Siegrist M. (2011). The less you know, the more you are afraid of a survey on risk perceptions of investment products. The Journal of Behavioral Finance, 12(1), 9-19. 